Running head: Ideological bias in social psychology measurement

\title{
Ideological measurement in social and political psychology
}

\author{
Craig A. Harper \\ Nottingham Trent University (UK) \\ Correspondence concerning this paper should be addressed to: \\ Dr. Craig Harper \\ Department of Psychology, Nottingham Trent University \\ 50 Shakespeare Street, Nottingham, NG1 4FQ, UK
}

Email: craigaharper19@ gmail.com Tel.: +44 (0)1158484718 Twitter: @CraigHarper19 


\begin{abstract}
As social psychology undergoes marked changes in its approach to research (e.g., open science practices, and addressing the replication crisis), it is important to undertake a full review of the tools and measures that we have at our disposal. In addition, the growing sense of political and ideological polarization in contemporary western democracies necessitates a coherent and internally consistent approach to studying politically and ideologically sensitive topics. This paper explores the measurement and study of such topics, and posits that claims about (a)symmetries between ideological partisans may be rooted in different measurement approaches. That is, studies (and researchers) who report widespread differences (asymmetries) between partisan liberals and conservatives typically adopt individual difference designs that examine trait-level constructs. In contrast, those who typically report similarities (symmetries) between these groups collect situationally derived data. A more consistent and ecologically valid approach to studying partisan engagement with political topics is advocated, focusing on situational responses to ideologically salient scenarios, rather than placing our focus on results from decontextualized self-report individual difference measures. Underpinning this review are three key assertions. First, that our ideological homogeneity as a field blinds us to hidden biases in our methods. Second, that the aforementioned (a)symmetry camps talk past each other by adopting different epistemological approaches. Third, that addressing these shortcomings can allow us to better conform to the Mertonian norms of communalism, universalism, disinterestedness, and organized skepticism. In doing so, we can revive our status as an open, accurate, and reproducible scientific field.
\end{abstract}

Key words: measurement, political polarization, ideological bias, individual differences, ideological symmetry hypothesis 


\section{Ideological measurement in social and political psychology}

The landscape of social psychology is currently undergoing some stark changes. Emerging practices to address the 'replication crisis' (Brandt et al., 2014; Lindsay, 2015) and the advent of increasingly open research practices, such as data- and materials-sharing, protocol and analytic pre-registration, and the peer-review of research plans before data are collected and results are known (Chambers, 2018; van't Veer \& Giner-Sorolla, 2016; Washburn et al., 2018) have led the field to consider some of the questionable research practices that have historically persisted in some spheres (Motyl et al., 2017; Ritchie, 2020).

Although these movements are clearly positive for the state of our science, they focus only on the higher-level processes associated with potential biases in research design and execution. These initiatives focus on addressing our conscious biases, such as switching outcome variables, continuing to collect data until $p<.05$, and manipulating our statistical models to produce parsimonious (and, importantly, statistically significant) accounts of human behavior (Ritchie, 2020). This paper, however, takes a look at the unconscious or hidden biases of social and personality psychological research, as applied in the political domain, to explore ideological basis of the conceptualization and interpretation of research in these areas. That is, there is an argument to be made that our current approaches to studying similarities and differences between those from competing political or ideological persuasions (from here, these similarities and differences are referred to as 'political/ideological (a)symmetries') may contain epistemic biases on the part of the field in the aggregate. In doing so, a critique of commonly used measurement tools in the political psychology domain is offered, and further suggestions for alternative approaches to researching ideological (a)symmetries are offered that are consistent with the continuing the recent advances in social psychological research. 
The first half of this paper presents a critical commentary of the existing theorizing on the importance of ideological diversity in (psychological) science, before a review of the existing literature on ideological (a)symmetries. Both of these review sections are necessary as they are interlinked, with the lack of diversity in social and political psychology guiding the questions we asked, and the tools that we used to answer them (Clark \& Winegard, 2020; Duarte et al., 2015; Honeycutt \& Jussim, 2020). Thus, the extent of our lack of diversity has implications for the types of studies we run, and subsequently the extent to which we find (a)symmetries in our studies.

Once these initial reviews have been provided, the central thesis of the article is introduced. Here, the distinction between dispositional (trait-level) and situational (behaviorlevel) (a)symmetries is described. The paper then presents a manifesto for reform, both in terms of revising our understanding and measurement of core constructs in a specific sense, and in terms of broadening the range of hypotheses that we test. At its core, the fundamental contribution of this article is thus not in its review of the extant literature on ideological (a)symmetries. It is in its 'call to action' for us to take stock of our existing practice and to work towards the Mertonian norms of communalism (collaborative practice), universalism (scientific validity across samples), disinterestedness (striving for accuracy, rather than confirmation), and organized skepticism (active attempts to scrutinize our fundamental assumptions).

\section{The importance of ideological diversity in psychological science}

The concept of diversity is becoming an increasingly controversial one. For decades, scholars examining diversity, prejudice, (in)tolerance, and intergroup hate have focused on so-called 'protected characteristics' (Chakraborti \& Garland, 2012), such as sex, age, race, religion, sexual proclivity, and, more recently, gender identity when examining levels of 
diversity in a range of settings (for a review, see Crawford, 2018). However, an emerging form of diversity - ideological diversity - is being increasingly discussed at the societal level, thanks predominantly to high-profile administrative developments (e.g., in the enactment of speech codes, speaker disinvitations, mandatory unconscious bias training, microaggression policies, and academic freedom disputes) on U.S. college campuses (Beinart, 2017; Jussim, 2018).

Broadly defined, ideological diversity refers to the presence of a plurality of different worldviews and epistemologies and is said to be one of the cornerstones of higher education (Routledge, 2016). However, work conducted by Duarte et al. (2015) established that social psychologists have become increasingly homogenous in their ideological views since the end of the second world war (see also Inbar \& Lammers, 2012). Up until the beginning of the 1960s, there was around a 2:1 ratio of self-reported liberals to republicans in among social psychologists (McClintock et al., 1965). This ratio represents twice as many liberals within the field as compared to conservatives, but this is not surprising given some of the established personality differences that have been consistently cited within the political psychological literature (for a review, see Jost, 2017a). For instance, liberals in the aggregate score higher on the 'Big 5' personality trait of openness to experience, which is comprised of an aspect related to openness to ideas and intellectual pursuits (DeYoung et al., 2007), which is consistent with the regular activity and general aims of a university education. Nonetheless, according to Redding (2015), “[n]o American institution has embraced cultural and demographic diversity more than the academy, and nowhere with greater enthusiasm than in the social sciences" (p. 1). In chasing this cultural and demographic diversity, the importance of ideological diversity, or diversity of thought, appears to have been lost (or perhaps rejected outright). This is exemplified by recent analyses showing that approximately two-thirds of academics in social psychology identify as politically liberal, and a Democrat-to-Republican 
voting ratio of more than 17:1 (Duarte et al., 2015; Inbar \& Lammers, 2012; Von Hippel \& Buss, 2018; though see Skitka (2012) for an earlier discussion of the limitations of trying to establish population estimates of field-wide ideological divisions).

The ideological homogeneity within social psychology poses a threat to each of the four Mertonian scientific norms, which reduces our adherence to the scientific process and an impartial pursuit of truth. In relation to communalism, our field is often siloed into competing 'teams' that appear to favor different views of ideological (a)symmetries. On the one hand are those researchers who adhere to the view that conservatives and liberals are distinctly different (e.g., Jost, 2017a). On the other hand, there are researchers who focus to a greater extent to ideological biases within social psychology that pathologizes political conservatism (e.g., Honeycutt \& Jussim, 2020). Somewhere in between these groups are scholars who suggest that partisans can behave in similarly motivated ways under specific conditions (e.g., Brandt, 2016; Frimer et al., 2017; Washburn \& Skitka, 2018). It has been noted that our samples are typically based in Western (usually US-based) samples (Rad, 2018), and we have numerous measures for similar constructs within our literature. These issues pose issues for the norm of universalism, with researchers being able to choose measures that most closely conform to their definitions of whatever topic they are studying. Relatedly, researchers who have spent years to develop theoretical frameworks have a vested interest in finding evidence in support of these ideas (flouting the Mertonian norm of disinterestedness). This can subsequently lead to a lack of organized skepticism, with erroneous work entering the literature due to a lack of sufficient scrutiny. Although the framework itself makes some interesting and replicable observations, the theory of system justification (see Jost, 2019) appears to conform to a framework that leads to a lack of disinterestedness and organized skepticism. For example, work examining the link between system justification motives (a proxy for political conservatism) and the denial of global warming (Feygina et al., 2010) 
failed to measure denial at all, instead measuring environmental attitudes, perceptions of the likelihood of an ecological crises, and the signing of a pro-environmentalist petition. More recently, high system justification was concluded as a source of disparaging humor perception at the expense of low-status groups (Baltiansky et al., 2020). However, a reanalysis of this dataset showed that the effect of system justification was attributable exclusively to those scoring particularly low on system justification, and their significantly lower perceptions of the funniness of jokes made at the expense of low-status groups (Purser \& Harper, 2020). The role of ideology in social psychological research thus opens the door to the possibility of bias in relation to the types of questions we answer, the measures we use to answer them, and the frames within which we interpret our data.

\section{Is there any explicit evidence of ideological bias in social and political psychology?}

Ideological diversity maintains a balanced and objective social scientific community (Clark \& Winegard, 2020; Duarte et al., 2015; Honeycutt \& Jussim, 2020; Peters et al., Jussim, 2020; Redding, 2013; Tetlock, 2012), while ideological homogeneity contributes to a closure of the ranks, and can limit the extent to which Mertonian scientific norms are adhered to. As highlighted by the recent 'Grievance Studies' episode, whereby three scholars published a series of hoax papers in leading critical theory journals (Lindsay et al., 2018; for critical commentaries see Lagerspetz, 2020; Lăzăroiu, 2019; Piedra, 2019), sacralizing dominant ideological positions can lead to low quality papers getting past the peer review process ${ }^{1}$. One paper in this series literally reworded the words of Adolf Hitler's Mein Kampf to promote the position of intersectional feminism, and received favorable peer reviews. The project explicitly highlights how such a sacralization can lead to contraventions of the

\footnotetext{
${ }^{1}$ Although it is acknowledged that the liberal-to-conservative lean in philosophy, sociology, and critical studies is much higher than within social and political psychology (e.g., Peters et al., 2020), this high-profile case is cited here as an example of the dangers of having a single dominant ideological frame within an ostensibly empirical discipline.
} 
Mertonian norms of universalism (social scientists rightly condemn Hitler's original work, but offered support for its wording when it was framed as supporting their ideological position), disinterestedness (the papers that were positively received typically advanced or conformed to sacralized theoretical frameworks), and organized skepticism (even the peer review process did not pick up on such outlandish claims suggesting that men might be leashed like dogs to curb their toxic masculinity, and that anal self-penetration could be a solution to reducing one's homophobia and transphobia; Smith, 2018; Wilson, 2018). ${ }^{2}$

There is no peer-reviewed evidence that the ideological lean of social psychology has led to hoax papers being accepted in this discipline. Indeed, Reinero et al. (2020) found no evidence that left-leaning research findings were over-represented within psychological research. However, this absence of evidence is not evidence of an absence of bias within the field in perhaps more subtle ways. For example, Eitan et al. (2018) reported how conservative ideas are evaluated more negatively than liberal alternatives, and that political conservatism is more commonly a topic in need of explanation in social psychological research. This suggests that conservative values may be viewed by many within social psychology as pathological, with explanations serving as potential theoretical bases for solving this apparent problem (potentially indicative of a contravention of the Mertonian norm of disinterestedness). However, Eitan et al. (2018) also found that academics' perceptions of the extent to which the aforementioned differences would be present were greater than the differences were in reality. That is, those sampled $(N=198$ academics, predominantly from within the social sciences) believed that conservatism would be judged more negatively, and be the topic of explanation, more than it actually was when examining study abstracts. This finding may suggest that the severity concerns of authors such as Redding (2001), and more

\footnotetext{
2 The author's names in Smith (2018) and Wilson (2018) are pseudonyms, in line with the nature of the Grievance Studies hoax project design. Both studies have since been retracted at their respective journals.
} 
recently Inbar and Lammers (2012) and Duarte et al. (2015), may be somewhat overblown. Further to this, Reinero et al. (2020) have reported that the ideological slant of social psychological research findings is unrelated to the work's replicability (though research rated by doctoral students as more ideological - in either direction - was found to be less likely to replicate). These authors suggested that this may be supportive of the view that concerns about the effect of ideology in social psychology on research quality are somewhat overblown, and that more attention should be paid to researchers' academic practices than to their political beliefs.

To some extent, the issue related to the degree of ideological bias in social psychology is a moot point. Just taking the lower bias figures from Eitan et al. (2018), the extent of conservative-to-liberal differences in evaluation and explanation of conservatism corresponded with a medium effect size, consistent with a majority of accepted and replicable results in social psychological research. Although Reinero et al.'s (2020) work on the lack of ideological effect on replicability is promising, this is also not particularly relevant to the target issue of this paper. More pertinent is the extent to which the field's ideological lean dictates (or, less extremely, guides) the types of research questions that are asked, and the tools used to answer them. For example, Inbar and Lammers (2012) found that liberal academics in social psychology did express some degree of willingness to suppress conservative research through the rejection of grant applications. According to Jussim (2012) this contributes to a type of liberal privilege in social psychology, wherein arguments consistent with a liberal worldview, and research that supports such a position, may receive less scrutiny (and more defense) than conservative-consistent alternatives. This reflects a contravention of the Mertonian norms of both communalism (ideologically incongruent research is suppressed, whether consciously or unconsciously) and organized skepticism (ideologically congruent research potentially receives less scrutiny). 
More recently, Clark and Winegard (2020) outlined how ideological biases have an effect on the content and quality of social science (see below for a more detailed exploration of the potential in-built ideological bias in our measurement approaches). They reviewed a range of literature supporting Inbar and Lammers' (2012) aforementioned conclusions about bias and discrimination against research ideas and findings that run counter to the liberal narrative. For example, ideological bias was reported to be an issue in relation to the evaluation of papers submitted for peer review at academic journals (see also Armstrong, 1997) and the granting of ethical approval for social science research (Ceci et al., 1992). There is also a case for citation rates being affected by ideological bias. This is particularly controversial at the present time in light of social justice calls for researchers to decolonize their reference lists, and include more women in their citations (Dion \& Mitchell, 2020; Dworkin et al., 2020). However, in one high-profile example of ideological bias in citation rates, Honeycutt and Jussim (2020) found that studies of gender biases in academic hiring do not appear to be cited in accordance with ostensible scientific quality. That is, a single study containing just 127 participants that found a bias against women in academic hiring (MossRacusin et al., 2012) been cited approximately ten-times more often than a second paper finding a bias in the opposite direction, and with five studies containing a total of 873 participants (Williams \& Ceci, 2015). Citation rates often drive perceptions of research quality when scholars conduct literature searches using open platforms (e.g., Google Scholar), and so such a bias has the potential to distort subsequent citation rates, create a false consensus of the accepted findings within a given field, and thus frame the direction of future research within the social sciences (Honeycutt \& Jussim, 2020). 


\section{Biases implicit in our existing measurement approaches}

As mentioned previously, much work in social and political psychology seeks to understand and explain the roots of political ideology. Several papers have argued that differences between 'open' and 'closed' mindsets form the core of the political differences (i.e., differences based upon policy preferences) between liberals and conservatives (Carney et al., 2008; Chirumbolo \& Leone, 2010; Jost et al., 2003; 2008; Onraet et al., 2011). These differences may be reflective of core personality traits, such as liberals' higher levels (in the aggregate) of openness to experience, and conservatives' comparatively higher levels of conscientiousness (particularly in relation to the personality aspect of orderliness; DeYoung et al., 2007; Jost et al., 2003).

Despite the apparent consistency of these observed differences (for review, see Jost, 2017a), some researchers have suggested that our measurement practices of these kinds of constructs may be confounded by ideological bias 'baked in' to the tools themselves (Duarte et al., 2015). For example, studies commonly use openness to experience that specifically ask about political preferences (e.g., Johnson \& Ostendorf, 1993; Petrescu \& Parkinson, 2014; Vander Molen et al., 2018) as this is provided as an item in the freely available IPIP personality item database (see https://ipip.ori.org/newNEODomainsKey.htm). Similarly, the NEO Personality Inventory (NEO-PI-R; Costa \& McCrae, 1992) contains a 'values' subscale for the measure of openness to experience. One this subscale there are items related to looking for religious authorities for guidance and developing new progressive and permissive social norms, with agreement leading to a reduction in the respondent's overall score for openness. However, it is difficult to reasonably suggest that such items of free of having an ideological slant (Charney, 2015), supporting Duarte et al.'s (2015) argument that ideological homogeneity in social and personality psychology may lead us to embed our own values into core measures of personality. 
Although the assertion here is not that such measures have been consciously designed to create the illusion of liberal openness, these practices do suggest that such an implicit assumption may be present in the design of newer iterations of personality inventories. However, openness has also been associated with a susceptibility to be receptive to pseudoprofound bullshit (Bainbridge et al., 2019) and conspiratorial beliefs (Swami et al., 2016), each of which is also associated with a propensity for conservative political voting and selflabelling (Jost et al., 2018; Nilsson et al., 2019; Pfattheicher \& Schindler, 2016). This potentially shows that the wording of trait-level openness measures may inflate the observed relationship between this trait and liberal voting proclivities, while downplaying situations wherein those with a more conservative outlook might demonstrate varied thinking and an openness to a range of alternative ideas.

In perhaps the most damning analysis of ideological measurement in social psychology, Reyna (2018) suggested that such bias has an effect in three distinct areas. First, ideological bias dictates what we measure. That is, the dominant ideological frame of group social status reflecting oppressor/oppressed status leads us to try explain prejudice through this hierarchical lens (as outlined earlier, conservative beliefs and behaviors are more often the topic for explanation in social psychology; Eitan et al., 2018; see also Duarte et al., 2015; Clark \& Winegard, 2020; Winegard et al., 2015). This may reflect why our literature is filled with references to 'right-wing authoritarianism', but comparatively little systematic investigation of 'left-wing authoritarianism' (though see Conway et al., 2017; Costello et al., 2020), why our moral disgust scales are used to predict responses to immigration and homosexuality (Aarøe et al., 2017; Inbar et al., 2009), and why we try to explain how women and individuals from working class communities could vote for conservative political candidates (Azevedo et al., 2017; Jost, 2017b; Jost et al., 2017). 
Second, ideological bias influences how we measure issues. For example, explicitly studying 'affirmative action' policies (compared to, for example, 'the hiring of qualified minorities') presents study stimuli via a liberal-congruent policy frame (Reyna, 2018; Tetlock, 2012). As such, the precise wording used in scales of core personality constructs may be tilted in the direction of evoking ideologically driven responses. Another example of this is present in the symbolic racism scale (Sears, 1988), where one item asks for respondents' endorsement of the following statement: 'It's really a matter of some people not trying hard enough; if Blacks would only try harder, they could be as well off as Whites". Although agreeing with this statement could conceivably indicate racist attitudes, the framing of the statement triggers a motivated response among those who believe that hard work is a key ingredient for life success (Sniderman \& Tetlock, 1986; Tetlock, 1994). That is, agreement could indicate racism as much as it indicates a general belief in meritocracy. To show that responses are driven by racism (rather than meritocratic beliefs), the same item would need to be answered differently when the reference group pertained to a racial minority than to an ostensibly disadvantaged member of a racial majority group. As such, it may be that our existing suite of individual difference measures are designed, if not explicitly then implicitly, to obtain differences between conservatives and liberals in the ways reported by Jost (2017a). These findings are then used as a basis for understanding larger-scale social movements, such as the election of President Donald Trump in 2016 (e.g., Farley, 2019; Tolbert et al., 2018). Some studies have even gone so far as to find 'anti-immigrant support' a predictor of voting for Trump, despite using support for Trump's own policies as a measure of such anti-immigrant sentiment (thus creating a tautology that all-but-guarantees a significant association between attitudes and voting outcomes; e.g., Major et al., 2018).

Even in cases where we do collect unbiased data from ideologically neutral measures, the way in which we test hypotheses may be informed by our prior beliefs or expectations. 
For example, the majority of work examining ideological (a)symmetries use simple linear regression models to examine relationships between ideology and the trait under investigation (e.g., Baltiansky et al., 2020; Kugler et al., 2014; Napier \& Jost, 2008; Stern et al., 2014). These tests are designed to obtain a conclusion that one group (or those identifying more with one side of the ideological spectrum) is more or less likely to endorse a proposition or possess a trait than another group. However, studies that have used more flexible models, or tested for curvilinear relationships between ideology and personality constructs, have found evidence of symmetry, with the extremity of ideological investment being more important than the direction of ideological beliefs (e.g., Toner et al., 2013; Zmigrod et al., 2020).

Third, ideological bias influences how we interpret our data. Reyna (2018) cites the tendency to look at mean differences between groups as an indicator of agreement or disagreement with particular propositions, or to determine whether particular groups score high vs. low in relation to a particular construct. However, this ignores the raw scores on such measures. For example, take a hypothetical case whereby, on a nine-point disagree-to-agree scale, Group A has an average score of 1.6, and Group B has an average score of 3.1, and that a $t$-test finds this difference to be statistically significant at $p<.001$. A researcher could interpret this in one of two ways. They might (correctly) conclude that Group A is significantly less likely to endorse the items than Group B. However, it is correct to interpret such a result as indicating that the trait under investigation is more characteristic of Group B than of Group A, as both groups' average is below the mid-point of potential scores. The degree to which researchers interpret data in this second, perhaps more erroneous, way is somewhat unclear. This is because a collection of work reporting ideological differences in happiness (Napier \& Jost, 2008), authoritarianism and social dominance orientation (Kugler et al., 2014), perceptions of ingroup consensus (Stern et al., 2014), and intergroup humor judgments (Baltiansky et al., 2020) simply report the relationship between such outcomes and 
ideology, rather than mean differences between partisan groups. Again, this apparent lack of statistical or methodological rigor may be related to a contravention of the Mertonian norm of disinterestedness (with researchers having a vested interest in finding results that conform to their personal ideological positions, or their previously-made theoretical contributions to the literature), and, as a result, lead to a lack of organized skepticism.

\section{Growing research into political and ideological (a)symmetries}

In light of the marked leftward lean within social psychological science, the seemingly motivated nature of political information processing (see e.g., Kahan, 2013; Redlawsk, 2002; Washburn \& Skitka, 2018) leaves us open to have a tendency to (at best) attempt to explain conservatism or (at worst) pathologize partisan conservatives while ignoring potential symmetries between them and partisan liberals (Duarte et al., 2015), consistent with the content analysis of published research presented by Eitan et al. (2018). This conceptual blindness manifests either in the motivated selection of study topics (e.g., prejudice against racial, religious and sexual minorities, but not members of majority group members; Jussim et al., 2015; Reyna, 2018), the motivated interpretation of data (Baltiansky et al., 2020; for commentary see Purser \& Harper, 2020; see also Washburn \& Skitka, 2018), or the explicit rejection of conclusions that highlight symmetries between ideological groups (Baron \& Jost, 2019).

In recent years, there has been a growing interest in the extent to which self-identifying liberals and conservatives possess a range of convergent or divergent personality characteristics, and express themselves in (dis)similar ways. This work is referred to as research into ideological (a)symmetries, with partisan differences labelled as asymmetries, and similarities labelled as symmetries (Ditto at al., 2019; Jost, 2017a). In this section, an 
overview of some of the highlights of this research is presented, and a critical explanation of the range of findings within the existing literature is outlined.

\section{Political partisans as asymmetric}

As indicated above, much research into political asymmetries has been focused around the pathologization of political conservativism. Indeed, in a seminal paper titled 'Political conservatism as motivated social cognition', Jost et al. (2003) opened with the following quote from George F. Will:

\section{"Conservatism is a demanding mistress and is giving me a migraine"}

Jost et al. (2003) then proceeded to present an impressive meta-analysis, including data from 88 samples containing a total of 22,818 participants, demonstrating how political conservatism is predicted by high levels of death anxiety, system instability, needs for order, structure, and closure, and fear of threat, but low levels of trait openness to experience, uncertainty tolerance, and self-esteem. In presenting this data, the authors made the convincing argument that conservative ideologies, focused around the core concepts of opposition to change on the one hand and the justification of inequality on the other, were at least in part the result of social-cognitive processes related to such epistemic, existential, and ideological motives.

The most convincing evidence for ideological asymmetries in the social-cognitive characteristics of liberals and conservatives was presented in a large-scale meta-analysis by Jost et al. (2018). They synthesized data from 181 samples (total $N>131,000)$ and reported that, comparative to liberals, conservatives scored significantly higher on measures of dogmatism (Everett, 2013; Jost et al., 2007; Pettigrew, 1958), cognitive rigidity 
(Kemmelmeier, 2007), intolerance of ambiguity (Kossowska \& van Hiel, 2003; Sidanius, 1978), and needs for closure, structure, and order (Altemeyer, 1998; Cornelis \& van Hiel, 2006; Golec de Zavala \& Van Bergh, 2007; van Hiel et al., 2004). In contrast, liberals scored significantly higher than conservatives on measures of uncertainty tolerance (Block \& Block, 2006; Jost et al., 2007), need for cognition (Benjamin, 2014; Kemmelmeier, 2010), cognitive reflection (Duriez \& Soenens, 2006; Kemmelmeier, 2010), and integrative complexity (Brundidge et al., 2014; Tetlock, 1983; 1984). Importantly, many of the studies used to measure such differences - particularly in relation to cognitive style (e.g., cognitive reflection and need for cognition) - use tasks that are ostensibly apolitical, suggesting that such differences are not reflective merely of engaging with political stimuli (e.g., Amodio et al., 2007; Zmigrod et al., 2018; though see below). One potential critique of this notion of a greater need for uncertainty reduction through structure, tradition, and a shared reality is that although the effects are around the expected magnitude in social scientific research, their absolute sizes are moderate at most. For example, Jost et al. (2018) review of ideological asymmetries in a desire for a shared social reality demonstrated correlations with ideology of between .13 to .27 (Hennes et al., 2012; Jost et al., 2017; Stern et al., 2014). In relation to a preference for tradition and conformity the correlations ranged from .07 to .17 when using voting preferences as an index of ideology (Caprara et al., 2006; Schwartz et al., 2010; Vecchione et al., 2013), to a more meaningful .31 to .40 when using liberal-conservative selfplacement (Jost et al., 2016). Looking at mean correlations between conservatism and a range of constructs associated with rigidity (e.g., intolerance of ambiguity, need for cognition, need for closer, Jost et al.’s (2018) meta-analysis reported average effects of a small magnitude. This is operationalized as correlation coefficients of no greater than around .20 , with the exception of dogmatism and cognitive rigidity $(r s \sim .40$ to .50$)$ 
Notwithstanding this critical point about effect size, the association between a need for order and political conservatism is explicitly formulated in the rigidity of the right model of ideology (Feldman \& Johnson, 2014; Hibbing et al., 2014; Jost et al., 2003; Malka \& Soto, 2015; van Hiel et al., 2010). According to this model, those with higher needs for security and consistency are drawn toward right-wing political ideas and actors due to the order and stability that these frameworks can offer. For example, in the sociocultural domain, preventing or slower immigration steadies the ratio of native-to-immigrant citizens and a consistency of host culture values and traditions, and proposals to limit LGBTQI+ rights are viewed as maintaining traditional family structures (Feldman \& Johnson, 2014; van Hiel et al., 2010). However, evidence for a link between a need for security and economic conservatism are more mixed. A range of researchers have found strong links in the direction of economic conservatism (Gerber et al., 2010; Jost \& Thompson, 2000), no relationship at all (Carney et al., 2008; Smith et al., 2011), or significant links between such needs for security and left-wing economic policy support (Golec, 2002; Johnston, 2013; Malka et al., 2014). The argument for a link to conservatism comes from the fact that right-wing policies are designed to maintain economic hierarchies (Malka \& Soto, 2015). However, left-wing policies are geared toward economic stability at the level of the individual, potentially making them attractive to those with a dispositional need for security (Federico et al., 2014). A detailed discussion of these differing associations is beyond the scope of this paper. However, the point to stress here is that the apparent asymmetry in such a dispositional need for order can result in either convergent or divergent political behavior as a result of the framing of the policy proposal under consideration (Malka \& Soto, 2015; Tetlock, 2012).

According to Jost (2017a), studying and acknowledging these asymmetries in the psychological characteristics of liberals and conservatives is the very essence of political psychology. He finds it "as perplexing as a cultural psychologist who is uncomfortable with 
the notion that there are meaningful cross-cultural differences in human behavior" (p. 194) that some political psychologists do not accept that large statistical differences exist between these groups. Dismissing the concerns of the opponents of ideological asymmetry research (e.g., that the framing of asymmetries explicitly places conservatives as being intellectually and morally inferior to liberals) with the phrase "so what?" (p. 195), Jost (2017a) suggests that it is not the role of social and political scientists to flatter or promote the views of either group. This is true. Instead, researchers in this field should be engaged in a critical and selfreflective process of refining their theories and methods to accurately measure their target constructs in a manner than is ideologically neutral (Jussim et al., 2015). This is not the case in many meta-analyses of ideological (a)symmetries. For example, in Jost's (2017a) analysis of asymmetries there are several instances whereby psychological constructs such as authoritarianism are used as direct proxies for political conservatism (e.g., Altemeyer, 1998; Cornelis \& van Hiel, 2006; Duriez \& Soenens, 2006; Kemmelmeier, 2010). In such studies, metaphorical deck is stacked explicitly against the possibility of left-wing authoritarianism (for example), with asymmetries being the almost guaranteed outcome. Developing methods of consistently examining asymmetries in a way that is free from such embedded values is essential to upholding the credibility and internal consistency of the field.

\section{Political partisans as symmetric}

Despite the clear and replicable temperamental, cognitive, and personality differences between political liberals and conservatives at the trait level (Jost, 2017a; Jost et al., 2003), there appears to be a substantial degree of symmetry in partisans' behavioral and/or situational interactions with political stimuli across the ideological spectrum (for a brief review of these studies, see Clark \& Winegard, 2020). For example, Brandt (2017) reported an analysis that showed how both liberals and conservatives express prejudice 
(operationalized using feeling thermometers in relation to positivity and/or negativity toward different groups) against a range of targets who are popularly linked with the opposite side of the ideological spectrum. For example, American liberals expressed warmth (i.e., liking) toward groups such as homosexuals, transgendered people, and Democrats, while disliking Christians and Republicans. In contrast, those with a more conservative orientation demonstrated the opposite trend. Brandt (2017) concluded that prejudice may be rooted predominantly in a model whereby partisans' perceptions of the target groups' ideological positions drive evaluations of those groups. As such, ideological prejudice is reflective of underlying stereotypes about particular groups, and the political positions and moral values that those groups may hold (see also Crawford et al., 2017; Crawford \& Pilanski, 2014; Wetherell et al., 2013).

In perhaps the largest and widest-ranging published meta-analysis of cross-spectrum partisan bias against outgroups (e.g., evaluations political outgroup actors and ideological opinions), Ditto et al. (2019) used data from 51 studies $(N>18,000)$ to calculate average bias scored for both liberals and conservatives. They found the meta-analyzed effect sizes for the two groups ( $r \mathrm{~s}=.24$ and .26 , respectively) that were not statistically different from one another, supporting the ideological symmetry hypothesis with regard to partisan bias. Indeed, in their own analysis of primary data using almost 1,000 partisans surveyed on YourMorals.com, Ditto et al. (2019) found that perceptions of ideological bias were themselves ideologically biased, with liberals perceiving increased bias among conservatives (comparative to among liberals), and conservatives demonstrating the opposite trend. This primary data was consistent with prior findings that suggest political liberals and conservatives engage in stereotypical thinking by exaggerating the moral differences between their respective groups (Graham et al., 2012). 
Baron and Jost (2019) have criticized and questioned Ditto et al.'s (2019) conclusions, stating that the studies included in this meta-analysis explicitly used highly polarizing topics that were unlikely to give rise of asymmetric findings. Instead, Baron and Jost (2019) suggest that more work be done examining the endorsement of beliefs that would demonstrate the aforementioned underlying cognitive differences between conservatives and liberals (see Jost, 2017a). They give examples such as belief in human-caused climate change, the oppressive nature of gun control laws, and that mass immigration serves as a potential national security threat. However, these authors' own biases emerge in this discussion, with these beliefs being presented as things that "would have seemed silly to liberal participants (and researchers)" (Baron \& Jost, 2019, p. 295). With the obvious exception of anthropogenic climate change, each of the examples given above are the topic of genuine political debate, and thus it is not necessarily true that "one 'side' holds far more true beliefs than the other" (Baron \& Jost, 2019, p. 295). Rather, it suggests that questioning the perceived wisdom of one's political opponents is a natural (and symmetric) cognitive process (for prior data on this, see Campbell \& Kay, 2014; Lord et al., 1979; Skitka, 2010; Taber \& Lodge, 2006).

In a study of the ideological interpretation of scientific data, Washburn and Skitka (2018) found that people are more likely to express skepticism when presented with research findings that run counter to their pre-existing ideological beliefs than when the same data were interpreted in a manner than was consistent with their ideological worldview. This finding was consistent among political liberals and conservatives, contrary to stereotypes about a conservative propensity to engage in science denial (Jost, 2017a; Lewandowsky et al., 2013). Instead, by manipulating the ideological salience of scientific findings, Washburn and Skitka (2018) found that liberal and conservative partisans interpret scientific findings in a symmetric way, with these judgments being driven by perceptions about the ideological stances of research teams, and the potential for political use of scientific findings (see also 
Nisbet et al., 2015). This conclusion is consistent with Brandt's (2017) work about the roots of ideological prejudice (see also Brandt \& Crawford, 2019; Crawford et al., 2014; 2017) , as well as prior theorizing about the psychological basis of science denial among conservatives (Gauchat, 2012; Mooney, 2005).

In relation to ideological partisans' interpretations of political arguments, Frimer et al., (2017) reported evidence for the motivated avoidance of outgroup members' political arguments on both sides of the ideological spectrum. That is, both Republicans and Democrats equally forfeited a monetary reward so that they would not be exposed to an outgroup member's voting reasons. Further, this motivated effect was heightened by both anticipated cognitive dissonance, and the need for a shared reality with the ingroup. This means that the motivation for avoiding outgroup members' ideas and vote justifications may stem from a desire to maintain a clear and coherent worldview, and a conscious effort to avoid the possibility that they may present a convincing argument. Thus, this represents a defensive process to maintain a coherent ingroup narrative about the way the world operates. This finding runs counter to the rigidity of the right hypothesis, which asserts that a propensity to maintain a clear and consistent worldview is most pronounced among conservatives (Feldman \& Johnson, 2014; Hibbing et al., 2014; Jost et al., 2003; Malka \& Soto, 2015; van Hiel et al., 2010). Further, this approach to avoiding and disparaging outgroup opinions - and, in particular, feeling threatened by such viewpoints - may also be reflected in the symmetric use of angry and otherwise negative language by ideological extremists on both the political left and right (Frimer et al., 2019). These findings could be related to a lack of cognitive flexibility on the parts of ideological extremists. Although cognitive rigidity is associated with those who vote or self-identity as conservatives, recent analyses using quadratic regression modelling has demonstrated that such inflexibility is most pronounced at both ends of the ideological distribution, rather than expressing itself in a 
purely linear way (Zmigrod et al., 2020). The psychological roots of these symmetries may speak more to an inflated sense of moral superiority among ideological extremists (Harris \& Van Bavel, 2020; Toner et al., 2013) than it does about an ambivalence about outgroup reasoning.

\section{Dispositions vs. behaviors in ideological (a)symmetries}

It is clear from the above analyses that those who self-identify as being politically liberal and conservative possess several important (a)symmetries a cross a number of different domains. Looking deeper at these reviews, however, it appears that there may be two 'tiers' of analysis at which to investigate such differences and similarities. The first tier may be labelled the dispositional level of analysis, which incorporates the core of who these individuals are. Constructs pertaining to the dispositional level include personality and thinking styles. The second tier may be labelled the situational level of analysis, which takes in behavioral manifestations of such core aspects of personality and includes information about interpersonal interaction styles in specific contexts. As will become clear, some responses studied at the situational level may be consistent over time. However, these are classified as situational because they do not necessarily represent a general or universal behavioral tendency. Rather, they are triggered by specific ideologically salient stimuli, and/or under specific situational circumstances. Examining these levels of analysis, political and ideological asymmetries appear to be present at the dispositional (trait) level, whereas the symmetric convergences between liberals and conservatives are observable at the situational (behavior) level.

It is in this distinction where another source of potential bias in the measurement of political and ideological (a)symmetries might be identified. As a field, social and personality psychologists have long made use of standardized self-report questionnaires. These 
questionnaires typically make use of a series of statements (or 'items'), against which respondents rate their level of (dis)agreement or (dis)liking. The standardization of such tools with regard to item wording necessitates a particular epistemological (and perhaps ideological) position to be embedded into the measures themselves. For example, the need for the scores on a particular questionnaire to be interpretable as meaning something in particular, such as 'high scores equate to high levels of conservatism' by necessity suggests that an individual differences approach to be embedded into the measurement procedure. This is both acceptable and necessary when examining high-level differences in personality and policy positioning. However, in using such an approach to examine the situational manifestation of behavior that is politically- or ideologically-salient (e.g., authoritarian-like tendencies to suppress the expression of counter-ideological viewpoints), researchers are hamstrung with regard to developing ideologically-neutral measures that are standardized for all potential respondents. That is, if such a measure is ideologically-framed (e.g., the rightwing authoritarianism scale; Altemeyer, 1981), scores on the measure will inevitably suggest that 'authoritarianism' is synonymous with the right wing of the political spectrum (consistent with the 'conservatism as pathology' argument advanced earlier in this paper). However, in an ideologically-neutral version of such a measure it would be the case that agreeing with some items (i.e., those framed in a liberal-consistent direction) and disagreeing with others (i.e., those framed in a conservative-consistent direction) both mean the same thing, making standardization and score interpretation difficult processes.

This limitation of the individual differences approach to studying political and ideological (a)symmetries requires us to be more innovative with measurement design. Although historically it was necessary to take an individual differences-based approach, due to in-person testing, or the anonymous completion of hard-copies of questionnaire packs, the vast majority of survey-based psychological research is now conducted online (Buhrmester et 
al., 2011; 2018; Clifford et al., 2015). Even laboratory-based studies can make use of online survey software for the completion of psychometric tests embedded within their designs.

This shift to online testing has afforded the as-yet-unadopted opportunity to consider wholesale changes to how we test our core constructs. This should encourage us to either: (1) present alternate forms of the same scale to participants based upon a previous (set of) answer(s), or (2) randomly present cross-ideological scenarios that ask for a standardized set of responses. In the first case, a fixed set of questionnaire items could be written with both left-wing and right-wing variants, with 'branches' being created with surveys to present the relevant iteration of the scale to individual participants on the basis of a prior response (e.g., their self-declared political affiliation). This equates to a continuation of the individual differences approach (measuring dispositions), but alleviates some of the issues mentioned earlier by enabling the collection of responses to items that are salient for each individual. In essence, researchers would tailor their stimuli to the political or ideological position of individual participants, while still being able to directly compare groups on a single construct.

The second option by definition represents a shift to an approach measuring (a)symmetries using a situational perspective. The process represents a more radical and profound departure from our existing measurement approaches. It requires us first deciding on definitions for core constructs that identify their essential features in a manner that allows for cross-spectrum expression (thus conforming to the Mertonian norm of universalism). Next in the process would be to formulate a range of scenarios (e.g., political topics, social contexts) within which that construct may be expressed by partisan liberals and conservatives. Researchers would then need to present these scenarios alongside nonideological scenarios, in a randomized order such that they can compare responses by partisans to scenarios that they should (vs. should not) find salient for their ideological 
position. In the sections that follow, some of our central constructs are considered with these developments in mind.

\section{Diversifying social psychological constructs in the political sphere}

In order to strengthen the argument that, as a field, we need to diversify our measures to make them less biased in the direction of finding asymmetries, it is necessary to identify core areas and concepts within the field where this practice is commonplace. Reforming these areas first is likely to open the door for reforms in other, and perhaps less established, areas of inquiry. In this section, four key core concepts - authoritarianism, social dominance orientation, disgust sensitivity, moral foundations - are outlined in relation to how they could be conceptualized in a manner that is consistent with an ideologically-neutral approach that is more akin to testing for (non-)equivalence in partisans' situational behavior.

\section{(Right-wing) authoritarianism}

The concept of (right-wing) authoritarianism (RWA; Adorno et al., 1950) refers to a tendency or willingness to uphold established social and hierarchical norms. This manifests in the inclination to act deferentially to established or recognized authorities within a given society or context, and to act with hostility and punitiveness against those who reject or challenge the status quo (Altemeyer, 1981; 1998). According to Stenner (2009), authoritarians value uniformity, and typically use group-based identity and, in some cases, coercive tactics, to achieve this.

The measurement of RWA is typically undertaken using self-report questionnaires, and thus comes from an individual differences perspective. The most widely cited measure is the 22-item RWA scale, developed by Altemeyer (2007). The RWA scale possesses items that relate to both the submission to authorities (e.g., "What our country really needs is a strong, 
determined leader who will crush evil, and take us back to our true path") and negativity and aggression toward those individuals or practices that threaten the established moral and social order (e.g., "Our country will be destroyed someday if we do not smash the perversions eating away at our moral fiber and traditional beliefs"). However, what is clear is that the very framing of these questions taps into topics that are more likely to elicit emotional responses on the political and ideological right (e.g., homosexuality and religion) than on the left. As such, it is little surprise that authoritarianism is deemed to be a right-wing trait.

It is important to acknowledge that there are some measures of authoritarianism that do not have explicitly political connotations (for a review, see Nilsson \& Jost, 2020). For example, Dunwoody and Funke (2016) used items in their measure such as "We should believe what our leaders tell us" and "Strong force is necessary against threatening groups" both of which tap into the core authoritarian tendencies of deference to authorities and aggressive rejection of dissent, but without explicitly conservative policies being attached. Nonetheless, higher scores on such ostensibly ideologically neutral measures are still correlated with preferences for right-wing or conservative candidates (Duckitt et al., 2010; Dunwoody \& Funke, 2016, Dunwoody \& Plane, 2019; Ludeke et al., 2018), with coefficients being around the same as those observed with traditional measures of RWA (Nilsson \& Jost, 2020). This does pose a potential issue for the argument that ideological asymmetries are related to inherent political content embedded within scales. However, this does not negate potential situational symmetries between liberals and conservatives. For example, it may be that as a standalone item, conservatives are more likely to endorse the view that we should follow leaders and use force to expel dissenters from the public square. That does not, however, mean that liberals do not also demonstrate these tendencies in practical situations, which is arguably a more important level of analysis than looking at how one self-places on a standardized scale. This argument supports those of author scholars who have suggested that 
self-placement on such scales is potentially being subject to a lack of insight, self-deception, and presentational biases linked to one's ideological self-image (Kahan, 2016; van Hiel et al., 2010). Such situational scenarios might look at presenting conservative- and liberalconsistent arguments about socially contentious topics (e.g., immigration, abortion, climate science) being presented by protagonists affiliated with each side of the political spectrum, and then examining partisan responses to this. If the asymmetry hypothesis is to be supported, one might expect comparatively higher levels of ingroup expert deference and outgroup defamation and silencing among conservatives. However, seeing these trends in both groups (e.g., conservatives and liberal both arguing for the deplatforming or silencing of experts advocating against their ideological beliefs) would provide evidence for an ideological symmetry in authoritarian behavioral tendencies. As such, while the individual differences perspective does indeed suggest an asymmetry, situational analyses have an enhanced potential to demonstrate, important, how partisans interact with each other and exacerbate the cycle of political polarization.

Notwithstanding these potential limitations in existing measures of authoritarianism, we have witnessed several high profile cases in recent years of behaviors that could conform to a definition of authoritarianism (i.e., the imposition of established social norms via coercive tactics; Stenner, 2009) emerging from the political left. For example, the Foundation for Individual Rights in Education (FIRE; a non-profit organization that ostensibly champions freedom of expression on university campuses) monitors campus disinvitation attempts (i.e., attempts to curtail or cancel the opportunities of externally-invited speakers to give an address or participate in a debate on university campuses). In a blog post for the Heterodox Academy, Stevens (2017) analyzed the political aspects of such attempts, and found a substantially higher number of attempted disinvitations coming from the ideological left of proposed speakers than from the right (though, among successful disinvitation attempts, there 
was approximately a 50:50 split). Among unsuccessful attempts (i.e., those events or debate participations that go ahead following a disinvitation attempt), the overwhelming majority ( $91 \%)$ of events that had moderate-to-substantial disruption had disinvitation attempts that emerged from the political left. Examples of disruption include the setting off of fire alarms and shouting down speaker mid-event. As such, there is evidence that authoritarian tendencies can be observed in traditionally left-leaning contexts at the situational level, and that these are not necessarily observable using our existing survey-based measures of authoritarianism.

Discussions of left-wing authoritarianism (LWA) have been prevalent in the political psychology literature for several decades (see Fasce \& Avendaño, 2020). However, these have typically been framed in such a way that equates them to far left-wing economic ideology and communism as an ideological frame (de Right et al., 2011; van Hiel et al., 2006). A recent study by Conway et al. (2018) sought to develop a LWA measure by writing parallel items to the RWA that conform instead to left-wing topics (e.g., science denial with regard to climate change, and eliminating religious influence from legislation). They reported support for an authoritarian symmetry hypothesis, with conservatives scoring higher on RWA than LWA, and liberals scoring higher on LWA than RWA. Nonetheless, these results were to be expected, with items on both scales tapping into politically salient topics from an individual differences perspective. In a more comprehensive examination of LWA, Costello et al. (2020) reported a series of five studies (total $N=6,292$ ) wherein they produced an index of LWA comprised of three underlying constructs. These were labelled 'anti-hierarchical aggression' (e.g., "Constitutions and laws are just another way for the powerful to destroy our dignity and individuality”), ‘conventionalism' (e.g., "Schools should be required by law to teach children about our country's history of racism, classism, sexism, and homophobia"), and 'top-down censorship' (e.g., "We must line up behind strong leaders who have the will to 
stamp out prejudice and intolerance"). As such, it may be possible to measure situational authoritarian tendencies using scenario-based tasks, with silencing of incongruent attitudes, the imposition of values, and deference to ideological thought leaders as criteria for determining authoritarian behavior.

\section{Social dominance orientation}

Social dominance theory (Sidanius \& Pratto, 1999; 2004) asserts that stable societies are maintained via the construction and maintenance of group-based hierarchies. Inevitably this leads to some social groups typically being placed in positions of higher status, and others in lower status roles (Kunst et al., 2017; Pratto et al., 1994; Wilson \& Sibley, 2013). According to established theorizing in political psychology, those with a greater propensity for endorsing the hierarchical status quo can be said to have a higher social dominance orientation (SDO). The fact that societies are stabilized by having hierarchies in place (Fischer et al., 2012), challenging existing structures can be costly - particularly to those in historically or socially disadvantaged positions (Kunst et al., 2017). As such, it might be expected to see relatively few challenges to the social quo under conditions of relative political or economic stability, and more discontent with established hierarchies under conditions of instability.

SDO is typically measured using the SDO scale, which was first published by Pratto et al. (1994) as a 16-item unidimensional questionnaire. In the development of the SDO, scores on this scale were positively associated with anti-Black racism, nationalism, political conservatism, military action against other countries, and cultural elitism $(.38>r<.55)$, and negatively associated with concerns about the wellbeing of others, welfare spending, women's/LGBT rights, and programs aimed at reducing environmental damage $(-.37>r<$ -.47). These correlations confirm SDO as being more related to expressions of ideology and 
social attitudes that are more in line with conservatism than liberalism. The most recent iteration is referred to as the $\mathrm{SDO}_{7}$ (Ho et al., 2015) has a bi-dimensional structure, with factor clusters related to group dominance (SDO-D) and anti-egalitarianism (SDO-E). Each of these dimensions has pro- and con-trait items as measurement points (i.e., positively and negatively coded statements underpin both subscales). The SDO-D scale is purported to measure a general tendency to support group-based hierarchy (as opposed to ingroup identification and preference; Jost \& Thompson, 2000). Ho et al. (2015) suggest that an inverse relationship between ingroup identification and SDO-D among African Americans in their sample confirms this. An alternative explanation to this interpretation would be that these participants are responding in a context that asserts that widespread implicit perceptions of racial inferiority exist (Sue, 2010), and are responding in a motivated way to items such as "Some groups must be kept in their place" or "Some groups of people are simply inferior to other groups" (Ho et al., 2015, p. 1028). The SDO-E scale, in contrast, represents a lack of concern about social inequality from a legislative or policy perspective, rather than a crude preference for the domination of one group over another. This may reflect a more subtle way of maintaining hierarchy, which according to Ho et al. (2015) may indicate a higher level of sophistication among high SDO-E individuals (comparative to high SDO-D individuals). In this regard, SDO-E may necessitate some degree of working with lower status groups (at least superficially) in order to obtain and maintain their compliance, whereas hierarchy maintenance is more overtly oppressive using an SDO-D approach (for further discussion of the potential sophisticated of the high status groups, see Chow et al., 2013).

As stated above, times of economic or political instability may lead to an emboldening of those groups who wish to destabilize and rebuild social hierarchies (Kunst et al., 2017). It is perhaps little surprise that there have been increasing calls for challenging the status quo and existing social hierarchies since the global financial crash of 2008 (for a review of this 
financial milestone, see Mishkin, 2011). According to Lukianoff and Haidt (2018) there has been a creeping shift leftwards on university and college campuses since the end of the $2000 \mathrm{~s}$ and the beginning of the 2010s. This has contributed to an increasing level of political and ideological polarization at the social and cultural level (see Keeter, 2015). Examples of this trend in polarization were provided earlier in this paper, and include the denial of the biological nature of sex or racial differences (e.g., Anomaly \& Winegard, 2019), the endorsement of groups involved in aggressive acts in response to perceptions of systemic racial inequality (Hunter \& Polk, 2016), and online disparagement of those voting for opposing political candidates using emotional rhetoric (Van Bavel \& Pereira, 2018).

Conventionally, a more pronounced SDO is associated with political conservatism, both in terms of an explicit rating of self-declared ideological orientation (e.g., Ho et al., 2012; 2015; Kugler et al., 2014; Pratto et al., 1994; van Hiel \& Mervielde, 2002; Wilson \& Sibley, 2013) and political preferences linked traditionally with the political right-wing (e.g., anti-environmental policies, opposition to welfare spending, and heterosexism; e.g., Eldridge \& Johnson, 2011; Ho et al., 2015; Milfont et al., 2018; Stanley \& Wilson, 2019). However, in recent unstable times we have seen moves from the political left-wing to attempt to force through changes to the social hierarchy in order to make amends for historical wrongs and place lower status group members above those of a traditionally higher status. Examples of these movements include the push for affirmative action in hiring (whereby quotas on the inclusion of minority candidates, and all-minority shortlists, have been enacted; Beaurain \& Masclet, 2016; Meshelski, 2016) and the use of the 'progressive stack' in academic and professional conference settings (whereby historically under-represented group members are called upon ahead of others, on the basis of their demographic characteristics; Wright, 2018). In a test of the ideologically objectionable premise model, Crawford (2012; Study 2) reported how those scoring high in relation to their SDO supported legacy-based college admissions to 
a greater extent than participants with a low SDO. However, judgments of a Supreme Court decision affirming race-based admissions policies (designed to redress the racial balance of student cohorts) were the reverse of this. Low-SDO participants (typically liberals) had a much higher level of support for race-based admissions than high-SDO participants (typically conservatives), showing that the same outcome (support for a legislatively-enforced admissions policy) is not necessarily predicted by SDO as it is currently measured, but by ideological conservatism or liberalism (proxy-operationalized as high- and low-SDO, respectively).

Recent work on the topic of equalitarianism (Winegard, 2018) has found that political liberals view particular social groups (e.g., women, Muslims, and ethnic minorities) as victims, and find academic findings about the superiority of high status groups less credible than when the same study concludes superiority among low status groups. This is in spite of an explicit acknowledgement among liberals that they should not rate identical information differently as a function of the target groups under investigation. Winegard's (2018) equalitarianism scale contains items that look conceptually similar to an SDO scale that would have salience for political liberals (e.g., "We should strive to make men and women equally represented in science fields", and "If we work hard enough, we can ensure that all ethnic groups have equal outcomes"). With this in mind, an ecologically valid way of reconceptualizing SDO may be to consider symmetries in the use of legislative force to alter the structure of the social hierarchy. Thus, among conservatives we might expect the traditional SDO scale to provide higher scores, but among liberals we might expect a more aggressive level of support for equalitarianism.

It is important to note that this shift in emphasis would change the way in which the field views SDO. However, this is not necessarily invalidating of the existing work in relation to this concept. The very labelling of social dominance orientation builds a particular 
ideological frame that taps into historical trends of group-based oppression and victimization. This is consistent with Duarte et al.'s (2015) concern that, as a field, we may have a tendency to implicitly embed our ideological values into measures of core politically relevant constructs. Instead of social dominance, an ideologically neutral way of viewing a psychological tendency to consider hierarchies might be to conceptualize and measure perceptions and behaviors about social organization. In this revised view, social dominance becomes the conservative facet of a symmetric tendency to organize society in line with one's own ideological view, with equalitarianism or a more aggressive for of social restructuring (e.g., the flipping of social hierarchies) as a far-left-wing manifestation of the impulse to enforce a particular social structure. Situationally based scenarios could then be developed to test the (a)symmetry hypotheses. For example, ideologically motivated support for the use of affirmative action in sectors that have gender imbalances (e.g., women in STEM vs. men in primary teaching or nursing) may reveal symmetric impulses on both ends of the political spectrum to attempt to use legislative force to equalize their representation. Such situations may take inspiration from existing SDO measure items. For example, "Some groups must be kept in their place" may lead to various scenarios for testing. It is difficult to imagine ideological effects of asking whether an expert (vs. a layperson) should 'keep in their place' on issues of medicine or science. However, it may be that those holding orthodox conservative or religious views may prefer to keep homosexuals 'in their place', while those on the extreme left might argue that those embodying the archetypical 'straight white men' should be eliminated from public discussions about broad social justice policies on account of their ostensibly privileged status. 


\section{Moral foundations}

One of the most influential models of ideological differences in moral thinking is the moral foundations theory (Graham et al., 2013; Haidt \& Graham, 2007; Haidt \& Joseph, 2004; Iyer et al., 2012). This framework sets out six innate and universal moral foundations (care/harm, fairness/reciprocity, ingroup/loyalty, authority/respect, purity/sanctity, and liberty) that are said to guide moral judgments and give rise to the expression of political and ideological orientations.

The measurement of each of the moral foundations is typically performed using the Moral Foundations Questionnaire (MFQ; Graham et al., 2010; Iyer et al., 2012). This is a 32item questionnaire (though only 30 items are scored, owing to the inclusion of two filler questions designed to catch those who are not attending to each item) divided into two sections. The first section asks about how relevant a context is when the respondent is making a moral decision (e.g., 'Whether or not someone suffered emotionally'; care/harm foundation), and the second asks respondents to rate their level of agreement with a range of moral propositions (e.g., 'Respect for authority is something all children need to learn'; authority/respect foundation). There are six items per each of the first five moral foundations. These were supplemented by Iyer et al. (2012) who added a further 12 items pertaining to economic liberty (six items) and social/lifestyle liberty (six items). Although the MFQ has been used in multiple studies, it is not without critique. Foremost of these concerns is the internal consistency of some of the subscales (operationalized as Cronbach's alpha coefficients; see Tamul et al., 2020), with poor reliability estimates being reported for each of the care/harm ( $\alpha=.50-.62$; Graham et al., 2009; Harper \& Hogue, 2019), fairness/reciprocity ( $\alpha=.39$-.69; Graham et al., 2009; 2011; 2012; Harper \& Hogue, 2019), ingroup/loyalty ( $\alpha$ $=.24-.58$; Graham et al., 2009; 2012), authority/respect ( $\alpha=.39-.64$; Graham et al., 2009), and purity/sanctity ( $\alpha=.58$; Graham et al., 2009) subscales. Harper and Hogue (2019; 
presented in their Supplemental File) went further to reanalyze their data from 428 Britons and uncovered only three usable subscales, relating broadly to themes of traditionalism, compassion, and liberty. These potentially represent the core moral values of conservatives, liberals, and libertarians, respectively.

In spite of the psychometrically questionable underpinnings of the MFQ, consistent ideological differences have been reported between self-identified liberals and conservatives (for a popular review, see Haidt, 2012). Cross-culturally, liberals are said to endorse a 'twochannel' view of morality, focusing predominantly on themes of care and fairness, whereas conservatives value all five of the original moral domains approximately equally (Graham et al., 2009; 2012; Johnson et al., 2017; Kugler et al., 2014; Rempala et al., 2016). These differences translate into voting preferences, with the endorsement of 'individualizing' foundations (care/harm and fairness/reciprocity) predicting left-wing voting, and the endorsement of 'binding' foundations (ingroup/loyalty, authority/respect, and purity/sanctity) predicting a preference for right-wing candidates (Franks \& Scherr, 2015). Self-identified libertarians appear to value liberty above all other moral concerns (Iyer et al., 2012). Indeed, this two (or perhaps three) higher-order factor view of morality appears to be a better fit to MFQ data than the straightforward five or six factor view advanced in the original moral foundations theory (see Davies et al., Harper \& Rhodes, 2020; Weber \& Federico, 2013). As such, it may be that the standard distinction between liberals and conservatives possessing two- and five-channel versions of morality (Graham et al., 2009; 2012; Johnson et al., 2017; Kugler et al., 2014; Rempala et al., 2016) is incorrect, and that the two groups differ on the degree to which they endorse these two (or perhaps three, when including liberty; see Harper \& Rhodes, 2020; Iyer et al., 2012) domains of moral intuition.

In recent analyses, however, it has been shown how the endorsement of the moral foundations appears to vary as a function of the targets of ostensibly immoral behavior. As 
reported by Voelkel and Brandt (2019), making the target of immoral behavior ideologically salient (i.e., from the respondent's political ingroup) produced higher levels of moral value endorsement across the range of moral foundations. Although this was consistent for both liberals and conservatives, there were still individual differences in the general endorsement of binding foundations when the political leaning of the targets were ambiguous, with liberal/conservative endorsements of individualizing/binding foundations being consistent with previous work using the MFQ. This was the case when endorsement of the moral foundations was measured using both the MFQ and a range of standardized moral foundations vignettes (Clifford et al., 2015). These findings highlight how even crossculturally reliable individual difference asymmetries between political liberals and conservatives can be observed as symmetries when measured using ecologically valid and ideologically varied stimuli, suggesting a need to manipulate the moral salience of stimuli in studies of ideological (a)symmetries.

Again, adopting a situational approach may facilitate this move toward enhancing the ecological validity of studying ideological (a)symmetries in the endorsement of different moral foundations. The emergence of standardized moral foundations vignettes (Clifford et al., 2015) is a positive sign, as it shows a willingness and striving within the field to move away from decontextualized individual differences questionnaires. However, these vignettes are still only framed as brief sentences, and focus on particular ideological frames. For example, groups seen as societally disadvantaged are presented as victims within the 'care/harm' vignettes (e.g., amputees, women, and overweight people), those mocking or degrading the U.S. are depicted in 'ingroup/loyalty' vignettes, and the 'purity/sanctity' vignettes predominantly contain themes related to sexual promiscuity, variation, and deviance. These contexts thus embed ideological frames within the vignettes themselves. Ideologically neutral or ecologically valid vignettes would sample a broad range of moral 
behaviors (with different targets of those behaviors; Voelkel \& Brandt, 2019) to be able to provide evidence for or against an (a)symmetry conclusion.

\section{Disgust sensitivity}

Disgust is defined as a moral emotion, whereby it drives our behavior and decisionmaking processes on the basis of how we feel about specific types of stimuli (Haidt, 2003; Yoder et al., 2018). According to Rozin et al. (2008), the emotion of disgust may have evolutionary origins with the function of preventing or discouraging humans from engaging with contaminating and poisonous substances. Researchers have formulated various measures of 'disgust sensitivity', which have attempted to operationalize the specific domains of disgust-inducing stimuli. Haidt et al.'s (1994) early scale identified eight domains of disgusteliciting stimuli: food, animals, bodily products, sex, bodily envelope violations (i.e., bodily injury), death, hygiene, and magic. Other measures have reported other clusters of disgust elicitors, such as core disgust, animal reminders, and contamination (Olatunji et al., 2007), or look at responses to specific disgust-eliciting stimuli (van Overveld et al., 2006).

Measures such as these have been reliably related not only to disgust-avoidant behaviors, but also to moral and political judgments. For example, it has consistently been reported that those scoring higher in relation to disgust sensitivity are more likely to self-label as being politically conservative (Inbar et al., 2009; Inbar et al., 2012; Terrizi et al., 2010; Xu et al., 2019). Trait disgust sensitivity has also been associated negative attitudes toward members of the LGBT community (e.g., Inbar et al., 2009), those who threaten traditional sexual values (e.g., pro-choice activists; Crawford et al., 2014), and immigrants (e.g., Aarøe et al, 2017). Further, inducing (e.g., with foul smells or bitter tasting drinks) or priming (e.g., with reminders to wash one's hands) disgust in laboratory contexts has been shown to lead to 
similar effects on intergroup attitudes and behaviors (e.g., Cunningham et al., 2013; Eskine et al., 2011; Inbar et al., 2012).

From this body of literature, it could be concluded that political conservatives have a sensitivity to disgust, and being placed in disgust-evoking contexts exaggerates conservative impulses. However, it could equally be the case that measures of disgust sensitivity, and outcome measures that examine the effects of inducing disgust, are biased in the direction of finding an association between disgust and conservatism. For example, Horberg et al. (2009) reported a link between both trait and state disgust and the condemnation of moral actions such as 'being sexually promiscuous', 'keeping an untidy and dirty living space', and 'buying music with sexually explicit lyrics'. These are all behaviors that are widely observed as being temperamentally and morally salient among conservatives (Brandt, 2017; DeYoung et al., 2007). Addressing this limitation, Elad-Strenger et al., (2019) examined disgust responses to an ideologically diverse range of elicitors. They found that both liberals and conservatives expressed higher levels of disgust when elicitors of this emotion were morally-salient to them (for liberals: tax evasion, environmental pollution, xenophobia; for conservatives: homosexuality, homeless people begging for money, disrupting a church service). When collapsing disgust scores across all elicitors, Elad-Strenger et al. (2019) found no relationship with political orientation, showing that disgust sensitivity is dependent on the eliciting situation, and symmetric between ideological groups. As alluded to earlier, the expression of disgust in relation to specific and identifiable targets may present in a consistent manner over time (and thus may be interpreted as a temperamental behavior). However, the elicitation of such responses appears to be tied to very specific topics, groups, or behaviors. In this sense, a general tendency to experience disgust is not supported, as the response is demonstrated in relation to situational triggers. These findings highlight the importance of taking participants' idiographic and ideological contexts into consideration when designing studies examining the 
role of moral emotions in the expression of political preferences (see also Crockett, 2017; Duarte et al., 2015; Elad-Strenger et al., 2019; Pliskin et al., 2020; Skitka, 2010).

\section{Developing ideologically salient measures of core political psychology constructs}

A major challenge in the unbiasing of our core measures of constructs such as authoritarianism, SDO, moral foundations, and disgust will be in the development of psychometrically sound and ecologically valid alternatives. In line with the ongoing debates within the field pertaining to reproducibility and bias-free theorizing (e.g., Motyl et al., 2017; Washburn et al., 2019), no formal scale drafts or sample scenario-based measures are offered in this article, because these should be developed via cross-field consensus and collaboration (in adherence to the Mertonian norm of communalism). However, the section that follows should be combined with the critiques presented above to formulate a potential roadmap toward the development of such tools.

Critics of such a radical approach may suggest that engaging in this process feels akin to changing the meaning of long-standing constructs changing to suit the whims and ideological biases of individual authors. This is not correct. Before commencing on a program of research to develop new measures of core political psychology constructs, it will first be necessary to produce a comprehensive database of politically and ideologically salient topics, groups, and political issues. Such an endeavor should by conducted in a collaborative manner across social and political psychology, and involve researchers from a variety of geographic, methodological, epistemological, and ideological backgrounds. In doing so, the risk of inadvertently infusing potential stimuli with researcher bias is markedly reduced from the outset, improving the scientific validity (universalism) of any agreed definitions and emergent measurement tools. 
As will now be clear, this article advocates for the development of measures that encompass a broad range of target stimuli. This is consistent with the ecological approach advocated by Kessler et al. (2015), who they argue that sampling responses to such a range of ideologically-salient stimuli has the potential to yield findings that run counter to the existing data about ideological asymmetries (see also Baron \& Jost, 2019; Reyna, 2018). Examples of where this broader sampling has begun to unearth more symmetries than asymmetries relate to ideological expressions of prejudice (Brandt \& Crawford, 2019; Crawford, 2018), disgust (Elad-Strenger et al., 2019), moral intuitions (Voelkel \& Brandt, 2019), ideological dogmatism (Harris \& Van Bavel, 2020), science denial (Washburn \& Skitka, 2018), and news legitimacy judgments (Harper \& Baguley, 2019).

This initial step is a substantial undertaking, and would serve as a useful starting point for small-scale or field-wide adversarial collaborations (Washburn et al., 2015; see below). That is, even if those with preferences for temperamental vs. situational research approaches differ in relation to their research outlook, finding some agreement on consistent working definitions of the types of topics, issues, and groups that are salient for partisan liberals and conservatives would be a useful addition to the field. This initial collaboration should foster a sense of communalism (fostering a sense of shared investment in this endeavor) and explicitly encouraging organized skepticism (by including researchers with a range of views).

A potential starting point for exploring topics for cross-ideological measurement is Brandt's (2017) work on ideological prejudice, wherein he examined feelings of warmth toward a range of demographic and social groupings. Although this work identified specific groups that liberals (e.g., homosexuals, immigrants) and conservatives (e.g., religious people, Republicans) were more favorable toward, it was somewhat limited by the range of groups being judged, and the exclusively American context of the sampling. More detailed work, sampling participants internationally, may establish a broader range of groups that those on 
the political left and right, respectively, feel affinity toward (and improve adherence to the Mertonian norm of universalism). Open-ended responses allowing individuals to freely list politically salient groups and issues (irrespective of the lean of that salience) would produce a rich dataset of issues to then subsequently test ideological warmth or preference.

The aim of this exercise should be to develop a database of potential topics, social groups, and policy positions that, in the first instance, can be substituted into measures of key constructs, just as Voelkel and Brandt (2019) were able to demonstrate ideologicallymotivated responses to the MFQ. However, developing such a bank of topics that are known to be ideologically salient across the political spectrum also allows for the development of situational scenarios, against which to assess standardized responses (e.g., self-reported disgust, propensities to restrict free expression, preferences for punishment for moral transgressors) can be assessed. Such a bank of materials should be made openly available (e.g., via the Open Science Framework; encouraging communalism) for the standardized measurement of core constructs across political psychological research.

\section{Broader recommendations for reducing the potential impact of ideological bias}

Although the above recommendations are quite specific in nature, and involve a move away from existing measures of politically salient constructs, there are more fundamental research strategies that scholars could enact to reduce the effects of their prior beliefs or expectations. Several examples of such practices have been initially proposed elsewhere (Motyl et al., 2017; Rakow et al., 2015; Washburn et al., 2015). Examples of these include adversarial collaborations, and the delineating of competing hypotheses, with research being designed to test these in explicit and straightforward ways.

An adversarial collaboration takes the form of a research team starting out with differing ideas about the story that their data will tell (Rakow et al, 2015). For example, one 
author may hypothesize ideological asymmetries in authoritarian tendencies (e.g., 'conservatives will respond in more authoritarian ways than liberals'), whereas a co-author may go into a project hypothesizing a symmetric relationship between ideology and authoritarianism. Arguably, a balance of prior opinions and predictions is the best way in which to reduce the effects of ideological bias in the research process, with each co-author acting as the other's critical peer reviewer. In one recent adversarial collaboration, Stern and Crawford (2020) sought to examine the effect of perceived dissimilarity on prejudice between liberals and conservatives. They found that, in both groups, perceived dissimilarity predicted increased prejudice (supporting the ideological symmetry hypothesis, and consistent with Crawford's a priori expectations). However, the effect was different for liberals and conservatives when considering the type of perceived dissimilarity under investigation. That is, when differences between the groups was stressed to be political in nature (e.g., views about gay marriage, gun control, or immigration), liberals expressed greater levels of negative emotion and prejudice than did conservatives. This relationship was reversed when dissimilarities were stressed in non-political terms (e.g., differences in food preference). These data support a more nuanced explanation for ideological (a)symmetries than may have otherwise been reported if these individual researchers had been working on projects geared around their specific expectations. This type of approach may be particularly suitable for the development of new tools for measuring our core constructs, where those favoring the temperamental asymmetry view place their ideas in direct comparison with those proposing a more situational approach demonstrating ideological symmetries. Mertonian norms of disinterestedness and organized skepticism are built into this approach at the design stage, with each author declaring their a priori positions and hypotheses, while the collaborative nature of this endeavor is quintessentially communal. 
Where adversarial collaborations are not possible, the testing of explicitly-defined competing hypotheses should be considered. This is often likely to be the case in social and political psychology owing the aforementioned lack of non-liberal or non-Democrat scholars in our field (Duarte et al., 2015; Inbar \& Lammers, 2012). In these cases, researchers should be encouraged to state competing hypotheses that they will test in their analyses (Washburn et al., 2015). In practice, this would mean that research teams must build a case for competing positions, mirroring the adversarial collaboration process within a non-adversarial setup by formulating hypotheses that might otherwise be ignored (Clark \& Winegard, 2020). By doing so, writers would need to demonstrate the conditions under which they would accept or reject each hypothesis, and what the implications of these acceptances or rejections would be. This process corresponds to Boghossian and Lindsay's (2018) notion of defeasibility - the explicit statement of the conditions under which a pre-held belief or hypothesis can be falsified. This latter recommendation can be embedded within more formal emergent structures, such as the open pre-registration of research protocols, the publication of open data and materials, and/or the submission of registered reports (Chambers, 2018; van't Veer \& Giner-Sorolla, 2016; Washburn et al., 2018), in order to protect ideologically homogeneous groups of researchers against accusations or suspicions of bias. Such changes to our research culture require a shift in our collective mindsets and in how research plans are formulated and enacted. However, given the ongoing adoption of open science practices within the broader field of psychological science, such behaviors are in line with emerging norms and a desire for greater transparency and reproducibility. Although communalism and disinterestedness are not necessarily addressed in these cases, organized skepticism is still inbuilt, as the criteria for accepting any named hypothesis are stated from the outset. 


\section{Conclusions}

The aim of this paper has been to explicitly delineate the causes and potential effects of ideologically based measurement practices in social and political psychological research, and to advance a preliminary plan for addressing this using field-wide collaboration and research design reform. Historically, our methods have necessitated standardized measures of individual differences (e.g., in relation to authoritarianism, moral foundations, and disgust sensitivity). However, with the growing use of online methods of data collection (Buhrmester et al., 2011; 2018) this necessity is reduced, as survey software can either: (1) branch participants to both generic and ideologically relevant versions of such measures, or (2) randomize a stimulus set for the comparison of responses across ideologically-salient scenarios. In this latter case, this means providing research participants with a range of scenarios that are ideologically slanted in both directions of the political spectrum (and, importantly, ideologically neutral). This makes it possible to directly examine whether temperamental traits that were previously thought to be asymmetric between liberals and conservatives actually express themselves in symmetric ways at the situational.

Away from these specific measurement-based issues, the adoption of more active adversarial collaborations, or the testing of explicitly defined and theoretically supported competing hypotheses where these are not possible, will help social psychological science to rebuild its reputation as a transparent and objective discipline. At its core, this article presents an argument that in addressing some of our existing problems we can also fix some of the problems that have dogged social psychology's status as a reproducible science. These processes allow us to demonstrate the four core Mertonian norms of science:

- Communalism: the development of normed definitions, stimulus topics, and measurement tools using field-wide collaboration and agreement. 
- Universalism: the inclusion of researchers from a range of diverse backgrounds and the use of samples from both Western and non-Western cultures to maximize the generalizability of ideologically based conclusions.

- Disinterestedness: the standardization of construct definitions and measurement tools to reduce the influence of researcher biases (e.g., personal ideological beliefs, or professional theoretical affiliations) in the interpretation of their data.

- Organized skepticism: researchers working together in adversarial collaborations, or the explicit statement of criteria for accepting competing hypotheses.

In doing so, we stand a greater chance of painting a picture of the political world as it truly is, and not as we perhaps wish it to be. 


\section{References}

Aarøe, L., Petersen, M. B., \& Arceneaux, K. (2017). The behavioral immune system shapes political intuitions: Why and how individual differences in disgust sensitivity underlie opposition to immigration. American Political Science Review, 111, 277-294. http://dx.doi.org/10.1017/S0003055146000770

Adorno, T. W., Frenkel-Brunswik, E., Levinson, D. J., Sanford, R. N. (1950). The authoritarian personality. New York: Harper and Row

Altemeyer, B. (2007). The authoritarians. Winnipeg, Canada: Author

Altemeyer, R. A. (1981). Right-wing authoritarianism. Winnipeg, Canada: University of Manitoba Press

Altemeyer, R. A. (1998). The other "authoritarian personality". Advances in Experimental Social Psychology, 30, 47-91. http://dx.doi.org/10.1016/S0065-2601(08)60382-2

Amodio, D. M., Jost, J. T., Master, S. L., \& Yee, C. M. (2007). Neurocognitive correlates of liberalism and conservatism. Nature Neuroscience, 10, 1246-1247. http://dx.doi.org/10.1038/nn1979

Anomaly, J., \& Winegard, B. (2019). The egalitarian fallacy: Are group differences compatible with political liberalism? Philosophia. Advance online publication. http://dx.doi.org/10.1007/s11406-019-00129-w

Armstrong, J. S. (1997). Peer review for journals: Evidence on quality control, fairness, and innovation. Science and Engineering Ethics, 3, 63-84. http://dx.doi.org/10.1007/s11948997-0017-3 
Azevedo, F., Jost, J. T., \& Rothmund, T. (2017). “Making America great again”: System justification in the U.S. presidential election of 2016. Translational Issues in Psychological Science, 3, 231-240. http://dx.doi.org/10.1037/tps0000122

Bainbridge, T. F., Quinlan, J. A., Mar, R. A., \& Smillie, L. D. (2019). Openness/intellect and susceptibility to pseudo-profound bullshit: A replication and extension. European Journal of Personality, 33, 72-88. http://dx.doi.org/10.1002/per.2176

Baltiansky, D., Craig, M. A., \& Jost, J. T. (2020). At whose expense? System justification and the appreciation of stereotypical humor targeting high vs. low status groups. Humor: International Journal of Humor Research. Advance online publication. http://dx.doi.org/10.31234/osf.io/7acbq

Baron, J., \& Jost, J. T. (2019). False equivalence: Are liberals and conservatives in the United States equally biased? Perspectives on Psychological Science, 14, 292-303. http://dx.doi.org/10.1177/1745691618788876

Beaurain, G., \& Masclet, D. (2016). Does affirmative action reduce gender discrimination and enhance efficiency? New experimental evidence. European Economic Review, 90, 350-362. http://dx.doi.org/10.1016/j.euroecorev.2016.04.009

Beinart, P. (2017). A violent attack on free speech at Middlebury. Retrieved from www.theatlantic.com/politics/archive/2017/03/middlebury-free-speechviolence/518667/

Benjamin, A. J. (2014). Chasing the elusive left-wing authoritarian: An examination of Altemeyer's right-wing authoritarianism and left-wing authoritarianism scales. National Social Science Journal, 43, 7-13 
Block, J., \& Block, J. H. (2006). Nursery school personality and political orientation two decades later. Journal of Research in Personality, 40, 734-749.

http://dx.doi.org/10.1016/j.jrp.2005.09.005

Boghossian, P., \& Lindsay, J. (2018). The Socratic method, defeasibility, and doxastic responsibility. Educational Philosophy and Theory, 50, 244-253.

http://dx.doi.org/10.1080/00131857.2017.1343111

Brandt, M. J. (2017). Predicting ideological prejudice. Psychological Science, 28, 713-722. doi:10.1177/0956797617693004

Brandt, M. J., Ijzerman, H., Dijksterhuis, A. P., Farach, F. J. Geller, J., Giner-Sorolla, R. ... van't Veer, A. (2014). The replication recipe: What makes for a convincing replication? Journal of Experimental Social Psychology, 50, 217-224.

http://dx.doi.org/10.1016/j.jesp.2013.10.005

Brundidge, J., Reid, S.A., Choi, S., \& Muddiman, A. (2014). The “deliberative digital divide": Opinion leadership and integrative complexity in the U.S. political blogosphere. Political Psychology, 35, 741-755. http://dx.doi.org/10.1111/pops.12201

Buhrmester, M. D., Kwang, T., Gosling, S. D. (2011). Amazon's Mechanical Turk: A new source of inexpensive, yet high-quality, data? Perspectives on Psychological Science, 6, 3-5. http://dx.doi.org/10.1177/1745691610393980

Buhrmester, M. D., Talaifar, S., \& Gosling, S. D. (2011). An evaluation of Amazon's Mechanical Turk, its rapid rise, and its effective use. Perspectives on Psychological Science, 13, 149-154. http://dx.doi.org/10.1177/1745691610393980 
Campbell, T. H., \& Kay, A. C. (2014). Solution aversion: On the relation between ideology and motivated disbelief. Journal of Personality and Social Psychology, 107, 809-824. http://dx.doi.org/10.1037/a0037963

Caprara, G. V., Schwartz, S. H., Capanna, C., Vecchione, M., \& Barbaranelli, C. (2006). Personality and politics: Values, traits, and political choice. Political Psychology, 27, 1-28. http://dx.doi.org/10.1111/j.1467-9221.2006.00447.x

Carney, D. R., Jost, J. T., Gosling, S. D., \& Potter, J. (2008). The secret lives of liberals and conservatives: Personality profiles, interaction styles, and the things they leave behind. Political Psychology, 29, 807-840. http://dx.doi.org/10.1111/j.1467-9221.2008.00668.x

Ceci, S. J., Peters, D., \& Plotkin, J. (1992). Human subjects review, personal values, and the regulation of social science research. In A. E. Kazdin (Ed.), Methodological issues \& strategies in clinical research (pp. 687-704). Washington, DC: American Psychological Association

Chakraborti, N., \& Garland, J. (2012). Reconceptualizing hate crime victimization through the lens of vulnerability and 'difference'. Theoretical Criminology, 16, 499-514. http://dx.doi.org/10.1177/1362480612439432

Chambers, C. (2018). Registered reports at BMJ Open Science: Making preclinical research match-fit for translation. Retrieved from http://blogs.bmj.com/openscience/2018/02/08/registered-reports-at-bmj-open-sciencemaking-preclinical-research-match-fit-for-translation/

Charney, E. (2015). Liberal bias and the five-factor model. Behavioral and Brain Sciences, 38, e139. http://dx.doi.org/10.1017/S0140525X14001174 
Chirumbolo, A., \& Leone, L. (2010). Personality and politics: The role of the HEXACO model of personality in predicting ideology and voting. Personality and Individual Differences, 49, 43-48. http://dx.doi.org/10.1016/j.paid.2010.03.004

Chow, R. M., Lowery, B. S., \& Hogan, C. M. (2013). Appeasement: Whites'strategic support for affirmative action. Personality and Social Psychology Bulletin, 39, 332-345. http://dx.doi.org/10.1177/0146167212475224

Clark, C. J., \& Winegard, B. M. (2020). Tribalism in war and peace: The nature and evolution of ideological epistemology and its significance for modern social science. Psychological Inquiry, 31, 1-22. http://dx.doi.org/10.1080/1047840X.2020.1721233

Clifford, S., Iyengar, V., Cabeza, R., \& Sinnott-Armstrong, W. (2015). Moral foundations vignettes: A standardized stimulus database of scenarios based on moral foundations theory. Behavior Research Methods, 47, 1178-1198. http://dx.doi.org/10.3758/s13428014-0551-2

Clifford, S., \& Jewell, R. M., \& Waggoner, P. D. (2015). Are samples drawn from Mechanical Turk valid for research on political ideology? Research and Politics, 2, 1-9. http://dx.doi.org/10.1177/2053168015622072

Conway, L. G., Houck, S. C., Gornick, L. J., \& Repke, M. A. (2018). Finding the Loch Ness monster: Left-wing authoritarianism in the United States. Political Psychology, 39, 10491067. http://dx.doi.org/10.1111/pops. 12470

Cornelis, I., \& van Hiel, A. (2006). The impact of cognitive styles on authoritarianism based conservatism and racism. Basic and Applied Social Psychology, 28, 37-50. http://dx.doi.org/10.1207/s15324834basp2801_4 
Crawford, J. T. (2012). The ideologically objectionable premise model: Predicting biased political judgments on the left and right. Journal of Experimental Social Psychology, 48, 138-151. http://dx.doi.org/10.1016/j.jesp.2011.10.004

Crawford, J. T. (2018). The politics of the psychology of prejudice. In J. T. Crawford and L. Jussim (Eds.), The politics of social psychology (pp. 99-115). New York, NY: Routledge

Crawford, J. T., Brandt, M. J., Inbar, Y., Chambers, J. R., Motyl, M. (2017). Social and economic ideologies differentially predict prejudice across the political spectrum, but social issues are most divisive. Journal of Personality and Social Psychology, 112, 383412. http://dx.doi.org/10.1037/pspa0000074

Crawford, J. T., Inbar, Y., \& Maloney, V. (2014). Disgust sensitivity selectively predicts attitudes toward groups that threaten (or uphold) traditional sexual morality. Personality and Individual Differences, 70, 218-223. http://dx.doi.org/10.1016/j.paid.2014.07.001

Crawford, J. T., \& Pilanski, J. M. (2014). Political intolerance, right and left. Political Psychology, 35, 841-851. http://dx.doi.org/10.1111/j.1467-9221.2012.00926.x

Crockett, M. J. (2017). Moral outrage in the digital age. Nature Human Behavior, 1, 769-771. http://dx.doi.org/10.1038/s41562-017-0213-3

Cunningham, E., Forestell, C. A., \& Dickter, C. L. (2013). Induced disgust affects implicit and explicit responses toward gay men and lesbians. European Journal of Social Psychology, 43, 362-369. http://dx.doi.org/10.1002/ejsp.1945

Davies, C. L., Sibley, C. G., \& Liu, J. J. (2014). Confirmatory factor analysis of the moral foundations questionnaire: Independent scale validation in a New Zealand sample. Social Psychology, 45, 431-436. http://dx.doi.org/10.1027/1864-9335/a000201 
dr Rigt, S., Mortelmans, D., \& Smits, T. (2011). Left-wing authoritarianism is not a myth, but a worrisome reality: Evidence from 13 Eastern European countries. Communist and ProstCommunist Studies, 44, 299-308. http://dx.doi.org/10.1016/j.postcomstud.2011.10.006

DeYoung, C. G., Quilty, L. C., \& Peterson, J. B. (2007). Between facets and domains: 10 aspects of the big five. Journal of Personality and Social Psychology, 93, 880-896. http://dx.doi.org/10.1037/0022-3514.93.5.880

Dion, M. L., \& Mitchell, S. M. (2020). How many citations to women is "enough"? Estimates of gender representation in political science. PS: Political Science \& Politics, 53, 107-113. http://dx.doi.org/10.1017/S1049096519001173

Ditto, P. H., Liu, B. S., Clark, C. J., Wojcik, S. P., Chen, E. E., Grady, R. H., Celniker, J. B., \& Zinger, J. F. (2019). At least bias is bipartisan: A meta-analytic comparison of partisan bias in liberals and conservatives. Perspectives on Psychological Science, 14, 273-291. http://dx.doi.org/10.1177/1745691617746796

Duarte, J. L., Crawford, J. T., Stern, C., Haidt, J., Jussim, L., \& Tetlock, P. E. (2015). Political diversity will improve social psychological science. Behavioral and Brain Sciences, 38, e130. http://dx.doi.org/10.1017/S0140525X14000430

Duckitt, J., Bizumic, B., Krauss, S. W., \& Heled, H. (2010). A tripartite approach to rightwing authoritarianism: The authoritarianism-conservativsm-traditionalism model. Political Psychology, 31, 685-715. http://dx.doi.org/10.1111/j.1467-9221.2010.00781.x

Dunwoody, P. T., \& Funke, F. (2016). The Aggression-Submission-Conventionalism Scale: Testing a new three factor measure of authoritarianism. Journal of Social and Political Psychology, 4, 571-600. http://dx.doi.org/10.5964/jspp.v4i2.168 
Dunwoody, P. T., \& Plane, D. L. (2019). The influence of authoritarianism and outgroup threat on political affiliations and support for antidemocratic policies. Peace and Conflict: Journal of Peace Psychology, 25, 198-210. http://dx.doi.org/10.1037/pac0000397

Duriez, B., \& Soenens, B. (2006). Personality, identity styles and authoritarianism: An integrative study among late adolescents. European Journal of Personality, 20, 397-417. http://dx.doi.org/10.1002/per.589

Dworkin, J. D., Linn, K. A., Teich, E. G., Zurn, P., Shinohara, R. T., \& Barrett, D. S. (2020). The extent and drivers of gender imbalance in neuroscience reference lists. ArXiV Preprints. Retrieved from https://arxiv.org/abs/2001.01002

Eitan, O., Viganola, D., Inbar, Y., Dreber, A., Johannesson, M., Pfeiffer, T., Thau, S., \& Uhlmann, E. L. (2018). Is research in social psychology politically biased? Systematic empirical tests and a forecasting survey to address the controversy. Journal of Experimental Social Psychology, 79, 188-199. http://dx.doi.org/10.1016/j.esp.2018.06.004

Elad-Strenger, J., Proch, J., \& Kessler, T. (2019). Is disgust a “conservative” emotion? Personality and Social Psychology Bulletin. Advance online publication. http://dx.doi.org/10.1177/0146167219880191

Eldridge, J., \& Johnson, P. (2011). The relationship between old-fashioned and modern heterosexism to social dominance orientation and structural violence. Journal of Homosexuality, 58, 382-401. http://dx.doi.org/10.1080/00918369.2011.546734

Eskine, K. J., Kacinik, N. A., \& Prinz, J. J. (2011). A bad taste in the mouth: Gustatory disgust influences moral judgment. Psychological Science, 22, 295-299. http://dx.doi.org/10.1177/0956797611398497 
Everett, J. A. (2013). The 12-item social and economic conservatism scale (SECS). PLoS ONE, 8, e82131. http://dx.doi.org/10.1371/journal.pone.0082131

Farley, J. E. (2019). Five decisive States: Examining how and why Donald Trump won the 2016 election. The Sociological Quarterly, 60, 337-353.

http://dx.doi.org/10.1080/00380253.2019.1629847

Fasce, A., \& Avendaño, D. (2020). Opening the can of worms: A comprehensive examination of authoritarianism. Personality and Individual Differences, 163, 110057. http://dx.doi.org/10.1016/j.paid.2020.110057

Federico, C. M., Johnston, C. D., \& Lavine, H. G. (2014). Context, engagement, and the (multiple) functions of negativity bias. Behavioral \& Brain Sciences, 37, 311-312. http://dx.doi.org/10.1017/S0140525X13002550

Feldman, S., \& Johnston, C. D. (2014). Understanding the determinants of political ideology: Implications of structural complexity. Political Psychology, 35, 337-358. http://dx.doi.org/10.1111/pops.12055

Feygina, I., Jost, J. T., \& Goldsmith, R. E. (2010). System justification, the denial of global warming, and the possibility of "system-sanctioned change". Personality and Social Psychology Bulletin, 36, 326-338. https://doi.org/10.1177\%2F0146167209351435

Fiagbenu, M. E., Proch, J., \& Kessler, T. (2019). Of deadly beans and risky stocks: Political ideology and attitude formation via exploration depend on the nature of the attitude stimuli. British Journal of Psychology. Advance online publication. http://dx.doi.org/10.1111/bjop.12430 
Fischer, R., Hanke, K., \& Sibley, C. G. (2012). Cultural and institutional determinants of social dominance orientation: A cross-cultural meta-analysis of 27 societies. Political Psychology, 33, 437-467. http://dx.doi.org/10.1111/j.1467-9221.2012.00884.x

Franks, A. S., \& Scherr, K. C. (2015). Using moral foundations to predict voting behavior: Regression models from the 2012 U.S. presidential election. Analyses of Social Issues and Public Policy, 15, 213-232. http://dx.doi.org/10.1111/asap.12074

Frimer, J. A., Brandt, M. J., Melton, Z., \& Motyl, M. (2019). Extremists on the left and right use angry, negative language. Personality and Social Psychology Bulletin, 45, 1216-1231. http://dx.doi.org/10.1177/0146167218809705

Frimer, J. A., Skitka, L. J., \& Motyl, M. (2017). Liberals and conservatives are similarly motivated to avoid exposure to one another's opinions. Journal of Experimental Social Psychology, 72, 1-12. http://dx.doi.org/10.1016/j.jesp.2017.04.003

Gerber, A. S., Huber, G. A., Doherty, D., Dowling, C. M., \& Ha, S. E. (2010). Personality and political attitudes: Relationships across issue domains and political contexts. American Political Social Review, 104, 111-133. http://dx.doi.org/10.1017/S0003055410000031

Golec, A. (2002). Need for cognitive closure and political conservatism: Studies on the nature of the relationship. Polish Psychological Bulletin, 33, 5-12

Golec de Zavala, A., \& Van Bergh, A. (2007). Need for cognitive closure and conservative political beliefs: Differential mediation by personal worldviews. Political Psychology, 28, 587-608. http://dx.doi.org/10.1111/j.1467-9221.2007.00591.x

Graham, J., Haidt, J., Koleva, S., Motyl, M., Iyer, R., Wojcik, S. P., \& Ditto, P. H. (2013). Moral foundations theory: The pragmatic validity of moral pluralism. Advances in 
Experimental Social Psychology, 47, 55-130. http://dx.doi.org/10.1016/B978-0-12407236-7.00002-4

Graham, J., Haidt, J., \& Nosek, B. A. (2009). Liberals and conservatives rely on different sets of moral foundations. Journal of Personality and Social Psychology, 96, 1029-1046. http://dx.doi.org/10.1037/a0015141

Graham, J., Nosek, B. A., \& Haidt, J. (2012) The moral stereotypes of liberals and conservatives: Exaggeration of differences across the political spectrum. PLoS ONE, 7, e50092. http://dx.doi.org/10.1371/journal.pone.0050092

Graham, J., Nosek, B. A., Haidt, J., Iyer, R., Koleva, S., \& Ditto, P. H. (2011). Mapping the moral domain. Journal of Personality and Social Psychology, 101, 366-385. http://dx.doi.org/10.1037/a0021847

Haidt, J. (2003). The moral emotions. In R. J. Davidson, K. R. Scherer, \& H. H. Goldsmith (Eds.), Handbook of affective sciences (pp. 852-870). Oxford: Oxford University Press

Haidt, J. (2012). The righteous mind. London: Penguin

Haidt, J., \& Graham, J. (2007). When morality opposes justice: Conservatives have moral intuitions that liberals may not recognize. Social Justice Research, 20, 98-116. http://dx.doi.org/10.1007/s11211-007-0034-Z

Haidt, J., \& Joseph, C. (2004). Intuitive ethics: How innately prepared intuitions generate culturally variable virtues. Daedalus, 133, 55-66

Haidt, J., McCauley, C., \& Rozin, P. (1994) Individual differences in sensitivity to disgust: A scale sampling seven domains of disgust elicitors. Personality and Individual Differences, 16, 701-713. http://dx.doi.org/10.1016/0191-8869(94)90212-7 
Harper, C. A. (2020). Revising the moral foundations questionnaire. PsyArXiv Preprints. http://dx.doi.org/10.31234/osf.io/p5fj8

Harper, C. A., \& Baguley, T. (2020). "You are fake news": Ideological (a)symmetries in perceptions of media legitimacy. PsyArXiv Preprints. http://dx.doi.org/10.31234/osf.io/ym6t5

Harper, C. A., \& Hogue, T. E. (2019). The role of intuitive moral foundations in Britain's vote on EU membership. Journal of Community and Applied Social Psychology, 29, 90103. http://dx.doi.org/10.1002/casp.2386

Harris, E., \& Van Bavel, J. J. (2020). Preregistered replication of "Feeling superior is a bipartisan issue: Extremity (not direction) of political views predicts perceived belief superiority". PsyArXiv Preprints. http://dx.doi.org/10.31234/osf.io/hfuas

Hennes, E. P., Nam, H. H., Stern, C., \& Jost, J. T. (2012). Not all ideologies are created equal: Epistemic, existential, and relational needs predict system-justifying attitudes. Social Cognition, 30, 669-688. http://dx.doi.org/10.1521/soco.2012.30.6.669

Hibbing, J. R., Smith, K. B., \& Alford, J. R. (2014). Differences in negativity bias underlie variations in political ideology. Behavioral \& Brain Sciences, 37, 297-350. http://dx.doi.org/10.1017/S0140525X13001192

Ho, A. K., Sidanius, J., Kteily, N., Sheehy-Skeffington, J., Pratto, F., Henkel, K., E., ..., \& Stewart, A. L. (2015). The nature of social dominance orientation: Theorizing and measuring preferences for intergroup inequality using the new $\mathrm{SDO}_{7}$ scale. Journal of Personality and Social Psychology, 109, 1003-1028.

http://dx.doi.org/10.1037/pspi0000033 
Ho, A. K., Sidanius, J., Pratto, F., Levin, S., Thomsen, L., Kteily, N., \& Sheehy-Skeffington, J. (2012). Social dominance orientation: Revisiting the structure and function of a variable predicting social and political attitudes. Personality and Social Psychology Bulletin, 38, 583-606. http://dx.doi.org/10.1177/0146167211432765

Honeycutt, N., \& Jussim, L. (2020). A model of political bias in social science research. Psychological Inquiry, 31, 73-85. http://dx.doi.org/10.1080/1047840X.2020.1722600

Horberg, E. J., Oveis, C., Keltner, D., \& Cohen, A. B. (2009). Disgust and the moralization of purity. Journal of Personality and Social Psychology, 97, 963-976. http://dx.doi.org/10.1037/a0017423

Hunter, D., \& Polk, E. (2016). Academic responses to Occupy Wall Street and Black Lives Matter. Peace Review, 28, 444-450. http://dx.doi.org/10.1080/10402659.2016.1237088

Inbar, Y., \& Lammers, J. (2012). Political diversity in social and personality psychology. Perspectives on Psychological Science, 7, 496-503.

http://dx.doi.org/10.1177/1745691612448792

Inbar, Y., Pizarro, D. A., \& Bloom, P. (2009). Conservatives are more easily disgusted than liberals. Cognition and Emotion, 23, 714-725. http://dx.doi.org/10.1080/02699930802110007

Inbar, Y., Pizarro, D. A., \& Bloom, P. (2012). Disgusting smells cause decreased liking of gay men. Emotion, 12, 23-27. http://dx.doi.org/10.1037/a0023984

Inbar, Y., Pizarro, D., Iyer, R., \& Haidt, J. (2012). Disgust sensitivity, political conservatism, and voting. Social Psychological and personality Science, 3, 537-544.

http://dx.doi.org/10.1177/1948550611429024 
Inbar, Y., Pizarro, D. A., Knobe, J., \& Bloom, P. (2009). Disgust sensitivity predicts intuitive disapproval of gays. Emotion, 9, 435-439. http://dx.doi.org/10.1037/a0015960

Iyer, R., Koleva, S., Graham, J., Ditto, P., \& Haidt, J. (2012). Understanding libertarian morality: The psychological dispositions of self-identified libertarians. Plos ONE, 7, e42366. http://dx.doi.org/10.1371/journal.pone.0042366

Johnson, J., \& Ostendorf, F. (1993). Clarification of the five-factor model with the abridged big five dimensional circumplex. Journal of Personality and Social Psychology, 65, 563576. http://dx.doi.org/10.1037//0022-3514.65.3.563

Johnson, K. M., Iyer, R., Wojcik, S. P., Vaisey, S., Miles, A., Chu, V., \& Graham, J. (2017). Ideology-specific patterns of moral indifference predict intentions to vote. Analyses of Social Issues and Public Policy. Online only article. http://dx.doi.org/10.1111/asap.12039

Johnston, C. D. (2013). Dispositional sources of economic protectionism. Public Opinion Quarterly, 77, 574-585. http://dx.doi.org/10.1093/poq/nft004

Jost, J. T. (2017a). Ideological asymmetries and the essence of political psychology. Political Psychology, 38, 167-208. http://dx.doi.org/10.1111/pops.12407

Jost, J. T. (2017b). Working class conservatism: A system justification perspective. Current Opinion in Psychology, 18, 73-78. http://dx.doi.org/10.1016/j.copsyc.2017.08.020

Jost, J. T. (2019). A quarter century of system justification theory: Questions, answers, criticisms, and societal applications. British Journal of Social Psychology, 58, 263-314. https://doi.org/10.1111/bjso.12297

Jost, J. T., Glaser, J., Kruglanski, A. W., \& Sulloway, F. J. (2003). Political conservatism as motivated social cognition. Psychological Bulletin, 129, 339-375. http://dx.doi.org/10.1037/0033-2909.129.3.339 
Jost, J. T., Langer, M., Badaan, V., Azevedo, F., Etchezahar, E., Ungaretti, J., \& Hennes, E. P. (2017). Ideology and the limits of self-interest: System justification motivation and conservative advantages in mass politics. Translational Issues in Psychological Science, 3, e1-e26. http://dx.doi.org/10.1037/tps0000127

Jost, J. T., Napier, J. L., Thórisdóttir, H., Gosling, S. D., Palfai, T. P., \& Ostafin, B. (2007). Are needs to manage uncertainty and threat associated with political conservatism or ideological extremity? Personality and Social Psychology Bulletin, 33, 989-1007. http://dx.doi.org/10.1177/0146167207301028

Jost, J. T., Nosek, B. A., \& Gosling, S. D. (2008). Ideology: Its resurgence in social, personality, and political psychology. Perspectives on Psychological Science, 3, 126-136. http://dx.doi.org/10.1111/j.1745-6916.2008.00070.x

Jost, J. T., Sterling, J., \& Stern, C. (2018). Getting closure on conservatism, or the politics of epistemic and existential motivation. In C. E. Kopetz \& A. Fishbach (Eds.), The motivation-cognition interface: From the lab to the real world: A Festschrift in honor of Arie W. Kruglanski (pp. 56-87). New York, NY: Routledge

Jost, J. T., \& Thompson, E. P. (2000). Group-based dominance and opposition to equality as independent predictors of self-esteem, ethnocentrism, and social policy attitudes among African Americans and European Americans. Journal of Experimental Social Psychology, 36, 209-232. http://dx.doi.org/10.1006/jesp.1999.1403

Jost, J. T., van der Linden, S., Panagopoulos, C., \& Hardin, C. D. (2018). Ideological asymmetries in conformity, desire for shared reality, and the spread of misinformation. Current Opinion in Psychology, 23, 77-83. http://dx.doi.org/10.1016/j.copsyc.2018.01.003 
Jussim, L. (2012). Liberal privilege in academic psychology and the social sciences:

Commentary on Inbar and Lammers (2012). Perspectives on Psychological Science, 7, 504-507. http://dx.doi.org/10.1177/1745691612455205

Jussim, L. (2018). The reality of the rise of an intolerant and radical left on campus.

Retrieved from https://areomagazine.com/2018/03/17/the-reality-of-the-rise-of-anintolerant-and-radical-left-on-campus/

Jussim, L., Crawford, J. T., Anglin, S. M., \& Stevens, S. T. (2015). Ideological bias in social psychological research. In J. P. Forgas, K. Fielder, \& W. D. Crano (Eds.), Social psychology and politics (pp. 91-110). New York, NY: Routledge

Kahan, D. M. (2013). Ideology, motivated reasoning, and cognitive reflection. Judgment and Decision Making, 8, 407-424

Kahan, D. M. (2016). The politically motivated reasoning paradigm, Part 2: Unanswered questions. In R. Scott \& S. Kosslyn (Eds.), Emerging trends in the social and behavioral sciences (pp. 1-15). New York, NY: Wiley

Keeter, S. (2015). Political polarization and the American public. Paper presented at the Consumer Federation of America Assembly. Washington, DC

Kemmelmeier, M. (2010). Authoritarianism and its relationship with intuitive-experiential cognitive style and heuristic processing. Personality and Individual Differences, 48, 4448. http://dx.doi.org/10.1016/j.paid.2009.08.012

Kessler, T., Proch, J., Hechler, S., \& Nägler, L. A. (2015) Political diversity versus stimuli diversity: Alternative ways to improve social psychological science. Behavioral and Brain Science, 38, e148. http://dx.doi.org/10.1017/S0140525X14001241 
Kossowska, M., \& van Hiel, A. (2003). The relationship between need for closure and conservative beliefs in Western and Eastern Europe. Political Psychology, 24, 501-518. http://dx.doi.org/10.1111/0162-895X.00338

Kugler, M., Jost, J. T., \& Noorbaloochi, S. (2014). Another look at moral foundations theory: Do authoritarianism and social dominance orientation explain liberal-conservative differences in "moral” intuitions. Social Justice Research, 27, 413-431. http://dx.doi.org/10.1007/s11211-014-0223-5

Kunst, J. R., Fischer, R., Sidanius, J., \& Thomsen, L. (2017). Preferences for group dominance track and mediate the effects of macro-level social inequality and violence across societies. Proceedings of the National Academy of Sciences, 114, 5407-5412. http://dx.doi.org/10.1073/ pnas.1616572114

Lagerspetz, M. (2020). “The grievance studies affair” project: Reconstructing and assessing the experimental design. Science, Technology, \& Human Values. Advance online publication. http://dx.doi.org/10.1177/0162243920923087

Lăzăroiu, G. (2019). Postmodernist sophistry, shoddy peer review, and academic dishonesty: How subjective science knowledge and patience for nonsense may cause (pseudo-)scholarly hoax. Boghossian et al. affair. Educational Philosophy and Theory, 51, 1408-1412. http://dx.doi.org/10.1080/00131857.2019.1590791

Lewandowsky, S., Oberauer, K., \& Gignac, G. E. (2013). NASA faked the moon landing therefore, (climate) science is a hoax: An anatomy of the motivated rejection of science. Psychological Science, 24, 622-633. http://dx.doi.org/10.1177/0956797612457686

Lindsay, D. S. (2015). Replication in psychological science. Psychological Science, 26, 1827 1832. http://dx.doi.org/10.1177/0956797615616374 
Lindsay, J., Boghossian, P., \& Pluckrose, H. (2018). Project fact sheet. Retrieved from https://leiterreports.typepad.com/files/project-summary-and-fact-sheet.pdf

Lord, C. G., Ross, L., \& Lepper, M. R. (1979). Biased assimilation and attitude polarization: The effects of prior theories on subsequently considered evidence. Journal of Personality and Social Psychology, 37, 2098-2109. http://dx.doi.org/10.1037/0022-3514.37.11.2098

Ludeke, S. G., Klitgaard, C. N., \& Vitriol, J. (2018). Comprehensively-measured authoritarianism does predict vote choice: The importance of authoritarianism's facets, ideological sorting, and the particular candidate. Personality and Individual Differences, 123, 209-216. http://dx.doi.org/10.1016/j.paid.2017.11.019

Lukianoff, G., \& Haidt, J. (2018). The coddling of the American mind: How good intentions and bad ideas are setting up a generation for failure. New York, NY: Penguin

Major, B., Blodorn, A., \& Blascovich, G. M. (2018). The threat of increasing diversity: Why many White Americans support Trump in the 2016 presidential election. Group Processes and Intergroup Relations, 21, 931-940. http://dx.doi.org/10.1177/1368430216677304

Malka, A., Osborne, D., Soto, C. J., Greaves, L. M., Sibley, C. G., \& Lelkes, Y. (2016). Binding moral foundations and the narrowing of ideological conflict to the traditional morality domain. Personality and Social Psychology Bulletin, 42, 1243-1257. http://dx.doi.org/10.1177/0146167216653936

Malka, A., \& Soto, C. J. (2015). Rigidity of the economic right? Menu-independent and menu-dependent influences of psychological dispositions on political attitudes. Current Directions in Psychological Science, 24, 137-142.

http://dx.doi.org/10.1177/0963721414556340 
Malka, A., Soto, C. J., Inzlicht, M., \& Lelkes, Y. (2014). Do needs for security and certainty predict cultural and economic conservatism? A cross-national analysis. Journal of Personality and Social Psychology, 106, 1031-1051. http://dx.doi.org/10.1037/a0036170

McClintock, C. G., Spaulding, C. B., \& Turner, H. A. (1965). Political orientation of academically affiliated psychologists. American Psychologist, 20, 211-221. http://dx.doi.org/10.1037/h0022172

Meshelski, K. (2016). Procedural justice and affirmative action. Ethical Theory and Moral Practice, 19, 425-443. http://dx.doi.org/10.1007/s10677-015-9633-1

Milfont, T. L., Bain, P. G., Kashima, Y., Corral-Verdugo, V., Pasquali, C., Johansson, L.-O., .., \& Einarsdóttir, G. (2018). On the relation between social dominance orientation and environmentalism: A 25-nation study. Social Psychological and Personality Science, 9, 802-814. http://dx.doi.org/10.1177/1948550617722832

Mishkin, M. (2011). Over the cliff: From subprime to the global financial crisis. Journal of Economic Perspectives, 25, 49-70. http://dx.doi.org/10.1257/jep.25.1.49

Mooney, C. (2005). The Republican war on science. New York, NY: Basic Books

Moss-Racusin, C. A., Dovidio, J. F., Brescoll, V. L., Graham, M. J., \& Handelsman, J. (2012). Science faculty's subtle gender biases favor male students. Proceedings of the National Academy of Sciences, 109, 16474-16479. http://dx.doi.org/10.1073/pnas.1211286109

Motyl, M., Demos, A. P., Carsel, T. S., Hanson, B. E., Melton, Z. J., Mueller, A. B., ..., \& Skitka, L. J. (2017). The state of social and personality science: Rotten to the core, not so bad, getting better, or getting worse? Journal of Personality and Social Psychology, 113, 34-58. http://dx.doi.org/10.1037/pspa0000084 
Napier, J. L., \& Jost, J. T. (2008). Why are conservatives happier than liberals? Psychological Science, 19, 565-572. http://dx.doi.org/10.1111/j.1467-9280.2008.02124.x

Nilsson, A., Erlandsson, A., \& Västfjäll, D. (2019). The complex relation between receptivity to pseudo-profound bullshit and political ideology. Personality and Social Psychology Bulletin, 45, 1440-1454. http://dx.doi.org/10.1177/0146167219830415

Nilsson, A., \& Jost, J. T. (2020). The authoritarian-conservatism nexus. Current Opinion in Behavioral Sciences, 34, 148-154. http://dx.doi.org/10.1016/j.cobeha.2020.03.003

Nisbet, E. C., Cooper, K. E., \& Garrett, R. K. (2015). The partisan brain: How dissonant messages lead conservatives and liberals to (dis)trust science. The Annals of the American Academy of Political and Social Science, 658, 36-66.

http://dx.doi.org/10.1177/0002716214555474

Olatunji, B. O., Williams, N. L., Tolin, D. F., Abramowitz, J. S., Sawchuk, C. N., Lohr, J. M., \& Elwood, L. S. (2007). The disgust scale: Item analysis, factor structure, and suggestions for refinement. Psychological Assessment, 19, 281-297. http://dx.doi.org/10.1037/10403590.19.3.281

Onraet, E., van Hiel, A., Roets, A., \& Cornelis, I. (2011). The closed mind: 'Experience' and 'cognition' aspects of openness to experience and need for closure as psychological bases for right wing attitudes. European Journal of Personality, 25, 184-197. http://dx.doi.org/10.1002/per.775

Peters, U., Honeycutt, N., De Block, A., \& Jussim, L. (2020). Ideological diversity, hostility, and discrimination in philosophy. Philosophical Psychology, 33, 511-548. http://dx.doi.org/10.1080/09515089.2020.1743257 
Petrescu, D. C., \& Parkinson, B. (2014). Incidental disgust increases adherence to left-wing economic attitudes. Social Justice Research, 27, 464-486.

http://dx.doi.org/10.1007/s11211-014-0221-7

Pettigrew, T. F. (1958). The measurement and correlates of category width as a cognitive variable. Journal of Personality, 26, 532-544. http://dx.doi.org/10.1111/j.14676494.1958.tb02350.x

Pfattheicher, S., \& Schindler, S. (2016). Misperceiving bullshit as profound is associated with favorable views of Cruz, Rubio, Trump and conservatism. PLoS ONE, 11, e0153419. http://dx.doi.org/10.1371/journal.pone.0153419

Piedra, L. M. (2019). The gift of a hoax. Qualitative Social Work, 18, 152-158. http://dx.doi.org/10.1177/1473325019833834

Pliskin, R., Ruhrman, A., \& Halperin, E. (2020). Proposing a multi-dimensional, contextsensitive approach to the study of ideological (a)symmetry in emotion. Current Opinion in Behavioral Sciences, 34, 75-80. http://dx.doi.org/10.1016/j.cobeha.2020.01.005

Pratto, F., Sidanius, J., Stallworth, L. M., \& Malle, B. F. (1994). Social dominance orientation: A personality variable predicting social and political attitudes. Journal of Personality and Social Psychology, 67, 741-763. http://dx.doi.org/10.1037/00223514.67.4.741

Purser, H., \& Harper, C. A. (2020). Low system justification drives ideological differences in joke perception: A critical commentary and re-analysis of Baltiansky et al. (2020). PsyArXiv Preprints. http://dx.doi.org/10.31234/osf.io/qv764

Rad, M. S., Martingano, A. J., \& Ginges, J. (2018). Toward a psychology of Homo sapiens: Making psychological science more representative of the human population. Proceedings 
of the National Academy of Sciences, 115, 11401-11405.

https://doi.org/10.1073/pnas.1721165115

Rakow, T., Thompson, V., Ball, L., \& Markovits, H. (2015). Rationale and guidelines for empirical adversarial collaboration: A Thinking \& Reasoning initiative. Thinking \& Reasoning, 21, 167-175. http://dx.doi.org/10.1080/13546783.2015.975405

Redding, R. E. (2001). Sociopolitical diversity in psychology: The case for pluralism. American Psychologist, 56, 205-215. http://dx.doi.org/10.1037/0003-066X.56.3.205

Redding, R. E. (2013). Politicized science. Society, 50, 439-446. http://dx.doi.org/10.1007/s12115-013-9686-5

Redding, R. E. (2015). Sociopolitical insularity is psychology's Achilles heel. Behavioral and Brain Sciences, 38, e155. http://dx.doi.org/10.1017/S0140525X14001393

Redlawsk, D. P. (2002). Hot cognition or cool consideration? Testing the effects of motivated reasoning on political decision making. The Journal of Politics, 64, 1021-1044. http://dx.doi.org/10.1111/1468-2508.00161

Reinero, D. A., Wills, J. A., Brady, W. J., Mende-Siedlecki, P., Crawford, J. T., \& Van Bavel, J. J. (2020). Is the political slant of psychology research related to scientific replicability? Perspectives on Psychological Science. Advance online publication. http://dx.doi.org/10.1177/1745691620924463

Rempala, D. M., Okdie, B. M., \& Garvey, K. J. (2016). Articulating ideology: How liberals and conservatives justify political affiliations using morality-based explanations. Motivation and Emotion, 40, 703-719. http://dx.doi.org/10.1007/s11031-016-9563-9

Reyna, C. (2018). Scale creation, use, and misuse. In J. T. Crawford and L. Jussim (Eds.), The politics of social psychology (pp. 81-98). New York, NY: Routledge 
Ritchie, S. (2020). Science fictions: Exposing fraud, bias, negligence and hype in science. London: Penguin

Routledge, C. (2016). We champion racial, gender, and cultural diversity - Why not viewpoint diversity? Retrieved from https://blogs.scientificamerican.com/guest-blog/wechampion-racial-gender-and-cultural-diversity-why-not-viewpoint-diversity/

Rozin, P., Haidt, J., \& McCauley, C. R. (2008). Disgust. In M. Lewis \& J. Haviland (Eds.), Handbook of emotions (pp. 757-776). New York, NY: Guilford Press

Schwartz, S. H., Caprara, G. V., \& Vecchione, M. (2010). Basic personal values, core political values, and voting: A longitudinal analysis. Political Psychology, 31, 421-452. http://dx.doi.org/10.1111/j.1467-9221.2010.00764.x

Sidanius, J. (1978). Intolerance of ambiguity and socio-politico ideology: A multidimensional analysis. European Journal of Social Psychology, 8, 215-235. http://dx.doi.org/10.1002/ejsp.2420080207

Sidanius, J., \& Pratto, F. (1999). Social dominance: An intergroup theory of social hierarchy and oppression. Cambridge: Cambridge University Press

Sidanius, J., \& Pratto, F. (2004). Social dominance theory: A new synthesis. In J. T. Jost \& J. Sidanius (Eds.), Political psychology (pp. 420-442). New York, NY: Psychology Press

Skitka, L. J. (2010). The psychology of moral conviction. Social and Personality Psychology Compass, 4, 267-281. http://dx.doi.org/10.1111/j.1751-9004.2010.00254.x

Skitka, L. J. (2012). Multifaceted problems: Liberal bias and the need for scientific rigor in self-critical research. Perspectives on Psychological Science, 7, 508-511. http://dx.doi.org/10.1177/1745691612454135 
Smith, K. B., Oxley, D. R., Hibbing, M. V., Alford, J. R., \& Hibbing, J. R. (2011). Disgust sensitivity and the neurophysiology of left-right political orientations. PLoS ONE, 6, e25552. http://dx.doi.org/10.1371/journal.pone.0025552

Smith, M. (2018). Going in through the back door: Challenging straight male homohysteria and transphobia through receptive penetrative sex toy use. Sexuality \& Culture, 22, 1542. http://dx.doi.org/10.1007/s12119-018-9536-0. [Retracted hoax paper]

Sniderman, P. M., \& Tetlock, P. E. (1986). Symbolic racism: Problems of motive attribution in political analysis. Journal of Social Issues, 42, 129-150.

http://dx.doi.org/10.1111/j.1540-4560.1986.tb00229.x

Stanley, S. K., \& Wilson, M. S. (2019). Meta-analysing the association between social dominance orientation, authoritarianism, and attitudes on the environment and climate change. Journal of Environmental Psychology, 61, 46-56.

http://dx.doi.org/10.1016/j.jenvp.2018.12.002

Stenner, K. (2009). Three kinds of "conservatism". Psychological Inquiry, 20, 142-159. http://dx.doi.org/10.1080/10478400903028615

Stern, C., \& Crawford, J. T. (2020). Ideological conflict and prejudice: An adversarial collaboration examining correlates and ideological (a)symmetries. Social Psychological and Personality Science. Advance online publication.

http://dx.doi.org/10.1177/1948550620904275

Stern, C., West, T. V., Jost, J. T., \& Rule, N. O. (2014). "Ditto heads": Do conservatives perceive greater consensus within their ranks than liberals? Personality and Social Psychology Bulletin, 40, 1162-1177. http://dx.doi.org/10.1177/0146167214537834 
Stevens, S. (2017). Campus speaker disinvitation trends (part 2 of 2). Retrieved from https://heterodoxacademy.org/campus-speaker-disinvitations-recent-trends-part-2-of-2/

Sue, D. W. (2010). Microaggressions in everyday life: Race, gender, and sexual orientation. Hoboken, NJ: Wiley

Swami, V., Weis, L., Lay, A., Barron, D., \& Furnham, A. (2016). Associations between belief in conspiracy theories and the maladaptive personality traits of the personality inventory for DSM-5. Psychiatry Research, 236, 86-90. http://dx.doi.org/10.1016/j.psychres.2015.12.027

Taber, C. S., \& Lodge, M. (2006). Motivated skepticism in the evaluation of political beliefs. American Journal of Political Science, 50, 755-769. http://dx.doi.org/10.1111/j.15405907.2006.00214.x

Tamul, D. J., Elson, M., Ivory, J. D., Hotter, J. C., Lanier, M. K., Wolf, J. T., \& MartinezCarrillo, N. I. (2020). Moral foundations' methodological foundations: A systematic analysis of reliability in research using the moral foundations questionnaire. PsyArXiv Preprints. http://dx.doi.org/10.31234/osf.io/shcgv

Terrizzi, J. A., Shook, N. J., \& Ventis, W. L. (2010). Disgust: A predictor of social conservatism and prejudicial attitudes toward homosexuals. Personality and Individual Differences, 49, 587-592. http://dx.doi.org/10.1016/j.paid.2010.05.024

Tetlock, P. E. (1983). Cognitive style and political ideology. Journal of Personality and Social Psychology, 45, 118-126. http://dx.doi.org/10.1037/0022-3514.45.1.118

Tetlock, P. E. (1984). Cognitive style and political belief systems in the British House of Commons. Journal of Personality and Social Psychology, 46, 365-375. http://dx.doi.org/10.1037/0022-3514.46.2.365 
Tetlock, P. E. (1994). Political psychology or politicized psychology: Is the road to scientific hell paved with good intentions? Political Psychology, 15, 509-529. http://dx.doi.org/10.2307/3791569

Tetlock, P. E. (2012). Rational versus irrational prejudices: How problematic is the ideological lopsidedness of social psychology? Perspectives on Psychological Science, 7 , 519-521. http://dx.doi.org/10.1177/1745691612454305

Tolbert, C. J., Redlawsk, D. P., \& Gracey, K. J. (2018). Racial attitudes and emotional responses to the 2016 Republican candidates. Journal of Elections, Public Opinion and Parties, 28, 245-262. http://dx.doi.org/10.1080/17457289.2018.1441846

Toner, K., Leary, M. R., Asher, M. W., \& Jongman-Sereno, K. P. (2013). Feeling superior is a bipartisan issue: Extremity (not direction) of political views predicts perceived belief superiority. Psychological Science, 24, 2454-2462.

http://dx.doi.org/10.1177/0956797613494848

Van Bavel, J. J., \& Perieira, A. (2018). The partisan brain: An identity-based model of political belief. Trends in Cognitive Sciences, 22, 213-224.

http://dx.doi.org/10.1016/j.tics.2018.01.004

van Hiel, A., Duriez, B., \& Kossowska, M. (2006). The presence of left-wing authoritarianism in western Europe and its relationship with conservative ideology. Political Psychology, 27, 769-793. http://dx.doi.org/10.1111/j.1467-9221.2006.00532.x

van Hiel, A., Onraet, E., \& de Pauw, S. (2010). The relationship between social-cultural attitudes and behavioral measures of cognitive style: A meta-analytic integration of studies. Journal of Personality, 78, 1765-1800. http://dx.doi.org/10.1111/j.14676494.2010.00669.x 
van Hiel, A., Pandelaere, M., \& Duriez, B. (2004). The impact of need for closure on conservative beliefs and racism: Differential mediation by authoritarian submission and authoritarian dominance. Personality and Social Psychology Bulletin, 30, 824-837. http://dx.doi.org/10.1177/0146167204264333

van Hiel, A., \& Mervielde, I. (2002). Explaining conservative beliefs and political preferences: A comparison of social dominance orientation and authoritarianism. Journal of Applied Social Psychology, 32, 965-976. http://dx.doi.org/10.1111/j.15591816.2002.tb00250.x

van Overveld, W. J. M., de Jong, P. J., Peters, M. L., Cavanagh, K., \& Davey, G. C. L. (2006). Disgust propensity and disgust sensitivity: Separate constructs that are differentially related to specific fears. Personality and Individual Differences, 41, 12411252. http://dx.doi.org/10.1016/j.paid.2006.04.021

Vander Molen, R. J., Kaplan, S., Choi, E., \& Montoya, D. (2018). Judgments of the dark tetrad based on Facebook profiles. Journal of Research in Personality, 73, 150-163. http://dx.doi.org/10.1016/j.jrp.2017.11.010

van’t Veer, A. E., \& Giner-Sorolla, R. (2016). Pre-registration in social psychology - A discussion and suggested template. Journal of Experimental Social Psychology, 67, 2-12. http://dx.doi.org/10.1016/j.jesp.2016.03.004

Vecchione, M., Caprara, G., Dentale, F., \& Schwartz, S. H. (2013). Values and voting: Reciprocal effects over time. Political Psychology, 34, 465-485. http://dx.doi.org/10.1111/pops.12011

Voelkel, J. C., \& Brandt, M. J. (2019). The effect of ideological identification on the endorsement of moral values depends on the target group. Personality and Social Psychology Bulletin, 45, 851-863. http://dx.doi.org/10.1177/0146167218798822 
Von Hippel, W., \& Buss, D. M. (2018). Do ideologically driven scientific agendas impede the understanding and acceptance of evolutionary principles in social psychology? In J. T. Crawford \& L. Jussim (Eds.), Politics of social psychology (pp. 17-35). New York, NY: Routledge

Washburn, A. N., Hanson, B. E., Motyl, M., Skitka, L. J., Yantis, C., Wong, K. M., ..., \& Carsel, T. S. (2018). Why do some psychology researchers resist adopting proposed reforms to research practices? A description of researchers' rationales. Advances in Methods and Practices in Psychological Science, 1, 166-173. http://dx.doi.org/10.1177/2515245918757427

Washburn, A. N., Morgan, G. S., \& Skitka, L. J. (2015). A checklist to facilitate objective hypothesis testing in social psychology research. Behavioral and Brain Sciences, 38, e161. http://dx.doi.org/10.1017/S0140525X14001435

Washburn, A. N., \& Skitka, L. J. (2018). Science denial across the political divide: Liberals and conservatives are similarly motivated to deny attitude-inconsistent science. Social Psychological and Personality Science, 9, 972-980.

http://dx.doi.org/10.1177/1948550617731500

Weber, C. R., \& Federico, C. M. (2013). Moral foundations and heterogeneity in ideological preferences. Political Psychology, 34, 107-126. http://dx.doi.org/10.1111/j.14679221.2012.00922.x

Wetherell, G. A., Brandt, M. J., Reyna, C. (2013). Discrimination across the ideological divide: The role of value violations and abstract values in discrimination by liberals and conservatives. Social Psychological and Personality Science, 4, 658-667. http://dx.doi.org/10.1177/1948550613476096 
Williams, W. M., \& Ceci, S. J. (2015). National hiring experiments reveal 2:1 faculty preference for women on STEM tenure track. Proceedings of the National Academy of Sciences, 112, 5360-5365. http://dx.doi.org/10.1073/pnas.1418878112

Wilson, H. (2018). Human reactions to rape culture and queer performativity at urban dog parks in Portland, Oregon. Gender, Place \& Culture. Advance online article. http://dx.doi.org/10.1080/0966369X.2018.1475346. [Retracted hoax paper]

Wilson, M. C., \& Sibley, C. G. (2013). Social dominance orientation and right-wing authoritarianism: Additive and interactive effects on political conservatism. Political Psychology, 34, 277-284. http://dx.doi.org/10.1111/j.1467-9221.2012.00929.x

Winegard, B. M. (2018). Equalitarianism: A source of liberal bias (Unpublished doctoral dissertation). Florida State University, Tallahassee, FL

Winegard, B., Winegard, B., \& Geary, D. C. (2015). Too paranoid to see progress: Social psychology is probably liberal, but it doesn't believe in progress. Behavioral and Brain Sciences, 38, e162. http://dx.doi.org/10.1017/S0140525X14001332

Wright, J. (2018). In defense of the progressive stack: A strategy for prioritizing marginalized voices during in-class discussions. Teaching Philosophy, 41, 407-428. http://dx.doi.org/10.5840/teachphil2018112198

Xu, X., Karinen, A. K., Chapman, H. A., Peterson, J. B., \& Plaks, J. E. (2019). An orderly personality partially explains the link between trait disgust and political conservatism. Cognition and Emotion, 34, 302-315. http://dx.doi.org/10.1080/02699931.2019.1627292

Yearley, S. (2005). Making sense of science. London: Sage

Yoder, A. M., Widen, S. C., \& Russell, J. A. (2016). The word disgust may refer to more than one emotion. Emotion, 16, 301-308. http://dx.doi.org/10.1037/emo0000118 
Zmigrod, L., Rentfrow, P. J., \& Robbins, T. W. (2018). The cognitive underpinnings of nationalistic ideology: The case of Brexit. Proceedings of the National Academy of Sciences, 115, E4532-E4540. http://dx.doi.org/10.1073/pnas.1708960115

Zmigrod, L., Rentfrow, P. J., \& Robbins, T. W. (2020). The partisan mind: Is extreme political partisanship related to cognitive inflexibility? Journal of Experimental Psychology: General, 149, 407-418. http://dx.doi.org/10.1037/xge0000661 